\title{
CALAHORRA ISLÁMICA (SIGLOS VIII-XI). NOTAS SOBRE LA ORGANIZACIÓN DE LOS ESPACIOS URBANO Y RURAL ${ }^{1}$
}

\author{
Tomás Sáenz de Haro \\ I.E.S. Valle del Jerte. Cáceres
}

El presente trabajo pretende reunir y contextualizar la información existente sobre Calahorra durante el periodo islámico, en pos de trazar las líneas maestras de la organización de la realidad urbana y del espacio rural que encuentra el monarca pamplonés García Sánchez III al reconquistar la ciudad. El laconismo de las crónicas y descripciones geográficas árabes nos obliga a buscar nuevas fuentes de información. En primer lugar, nos centramos en la documentación cristiana elaborada por la generación inmediatamente posterior a dicha reconquista, es decir, entre los años 1045 y 1076; no obstante, también empleamos menciones documentales que, aunque fuera de este ámbito cronológico, se pueden referir al momento islámico. En segundo lugar, estudiamos la microtoponimia calagurritana, tanto la contenida en dichos diplomas como la todavía existente, asumiendo el elevado riesgo de error que ello conlleva para quienes ignoramos la lengua árabe. Y, por último, recurrimos a los resultados de las prospecciones y excavaciones arqueológicas Ilevadas a cabo en la ciudad y su territorio circundante, a pesar de tratarse en su mayor parte de intervenciones puntuales. Además, el carácter fragmentario de los datos obtenidos hace imprescindible la continua referencia a estudios que aborden el Islam español en general y a investigaciones específicas acerca de otras poblaciones andalusíes, sobre todo aquellas asimilables a Calahorra

1. No podemos comenzar sin agradecer el apoyo y la información ofrecidos por José Luís Cinca Martínez, presidente de los "Amigos de la Historia de Calahorra", Juan Manuel Tudanca, Ana Jesús Mateos y Fco. Javier Goicolea, así como las indicaciones y correcciones planteadas por el profesor Felipe Maillo Salgado. Ellos no son responsables de los errores que puedan contener estas líneas, pero sí de que su número sea menor que en el caso de no haber contado con su ayuda. 
por su evolución histórica (Sagunto, Lleida, Bocairent,...) o proximidad geográfica (Tudela, Olite, Zaragoza, Huesca,...).

Trabajar con informaciones escasas y fragmentarias, muchas de ellas recopiladas "a posteriori" y susceptibles de variadas interpretaciones, nos conduce a excesivas extrapolaciones sobre el escenario calagurritano de las realidades constatadas en otras ciudades andalusíes. Por tanto, en las siguientes líneas, abusamos de palabras y expresiones como "quizás", "seguramente", "es posible"..., recurrimos con gran frecuencia a las notas a pie de página, las preguntas y conjeturas superan con mucho a las certezas,...; de ahí que la validez de las conclusiones obtenidas, como la de cualquier hipótesis, esté a expensas de que otros investigadores presenten argumentos más aceptables o de la obtención de nuevas informaciones, sobre todo a partir de la arqueología. Esperamos que estas circunstancias tengan pronto lugar y nos permitan conocer mejor la Calahorra islámica; de ser así, este modesto artículo habrá tenido sentido.

Comenzamos estableciendo el punto de partida, la Calahorra tardo-antigua, y contextualizando la evolución de esta urbe dentro del devenir histórico andalusí. A continuación, nos centramos en el estudio de los espacios de la ciudad islámica y de sus funciones, así como de la organización productiva y social de su entorno rural.

\section{Calahorra durante la Antigüedad Tardía (siglos V al VII)}

El municipio romano Calagurris Iulia Nassica se halla dispuesto en una meseta elevada sobre el río Cidacos, unos tres kilómetros antes de su desembocadura en el Ebro. Inicialmente, se trata de una ciudad abierta con la única excepción de la zona más elevada, el actual Rasillo de San Francisco; esta acrópolis, que acogería edificios singulares (templos, residencia de elites urbanas,...), queda rodeada por una muralla erigida en el siglo I d. C $\mathrm{C}^{2}$. Las invasiones bárbaras del siglo III y la disolución de la autoridad imperial a lo largo del

2. Sigue las actuales calles Horno, Sastres, Cabezo, Murallas y Cuesta de la Catedral. La existencia de estas acrópolis amuralladas no es extraña en otras ciudades romanas del Valle del Ebro. IGUÁCEL DE LA CRUZ, P.: "El trazado urbano". Así era la vida en una ciudad romana: Calagurris Iulia. Calahorra, 2002, p. 43. Mientras Gómez Pantoja, J. Carlos y M. Pilar Sáenz Preciado y Luezas Pascual localizan aquí el castro vascón destruido por Afranio en el 72 a. C., Iguácel de la Cruz estima que, en virtud de los hallazgos arqueológicos, la población prerromana se encontraba diseminada por toda la meseta. GÓMEZ PANTOJA, J.: "La ciudad romana de Calahorra". Symposium de ciudades augusteas. Zaragoza, 1978, vol. II, pp. 185-188. SÁENZ PRECIADO, J. C. y M. P.: "Excavaciones y consolidación en el recinto amurallado de Calahorra". Estrato. Revista Riojana de Arqueología, V (1994), p. 48. LUEZAS PASCUAL, R. A.: "Arqueología urbana en Calahorra". Estrato. Revista Riojana de Arqueología, IX (1998), pp. 24-34. EQUIPO CALAGURRIS IULIA: "El proyecto Calagurris Iulia: actuaciones efectuadas durante el año 2000". Estrato. Revista Riojana de Arqueología, XII (2000), pp. 15 y ss. 
siglo $\vee$ motivan la fortificación de la ciudad, eso sí, con una considerable reducción del espacio habitado. El perímetro occidental de esta nueva muralla recorrería las actuales calles Portillo de la Plaza, Doctor Fleming, Sol, Cavas, Justo Aldea y traseras de San Blas. Más dudas ofrece el trazado del muro oriental. Gómez Pantoja lo sitúa siguiendo los torreones y muros, hoy ya desaparecidos o arruinados, que se ubicaban en la plaza del Raso y en la calle Carreteros; en cambio, Iguácel de la Cruz considera estos restos como medievales y prolonga la muralla romana hasta el límite meridional de la meseta, englobando la citada acrópolis altoimperial ${ }^{3}$.

La Antigüedad Tardía supone un periodo de fuerte inestabilidad en la cuenca del Ebro. Este escenario asiste a los saqueos de cántabros y vascones sobre las fértiles tierras del valle, a las incursiones de los francos procedentes de más allá de los Pirineos y a las operaciones militares visigodas frente a ambos ${ }^{4}$. En tales circunstancias, Calahorra constituye un punto fortificado del estado toledano ante las amenazas septentrionales ${ }^{5}$; al mismo tiempo, su condición de sede episcopal la convierte en una referencia político-religiosa respecto del territorio circundante ${ }^{6}$.

Esta nueva coyuntura determina la metamorfosis del municipio romano en un nuevo modelo de "civitas" propio de la tardoantigüedad. La novedad urbanística más relevante de la Calahorra hispanovisigoda es el descenso desde el cerro amurallado a la ocupación de la terraza inferior localizada junto al cauce del Cidacos, espacio donde se ubica la actual catedral. La localización de la iglesia catedralicia en este espacio marginal y situado extramuros ha sido explicada desde dos puntos de vista. Por un lado, Espinosa Ruiz y, sobre todo, Castellanos García consideran decisiva la construcción allí del baptisterio conmemorativo del martirio de los santos Emeterio y Celedonio, edificio cantado por Prudencio en el himno VIII de su "Peristephanon". Este lugar se convierte en un "Locus Sacrum", escenario de una "Memoria Martyrium", celebración litúrgica que, además de ensalzar el protagonismo del obispo y de los grandes propietarios fundiarios, reclama el "Patrocinium Caeleste" para el territorio calagurrita-

3. GÓMEZ PANTOJA, J.: “La ciudad romana..., pp. 185-188. IGUÁCEL DE LA CRUZ, P.: “EI trazado..., pp. 42, 43 y 48. En cambio, Andrés Hurtado y Sáenz Preciado conceden a los torreones de la plaza del Raso y de la calle Carreteros un origen altoimperial. ANDRÉS HURTADO, G.: "Los torreones de la Plaza del Raso (Calahorra)". Kalakorikos, II (1997), pp. 43-54. SÁENZ PRECIADO, J. C. y M. P.: "Excavaciones y consolidación en..., p. 49.

4. CASTELLANOS GARCÍA, S.: Calagurris tardoantigua. Poder e ideología en las ciudades Hispanovisigodas. Murcia, 1999, pp. 15 y ss. "Aproximación a la historia política del Alto Valle del Ebro durante los siglos V-VI d. C.". Brocar, XVIII (1994), pp. 119-138.

5. Acoge la amonedación del monarca visigodo Suintila entre 621 y 631. CASTELLANOS GARCÍA, S.: Hagiografía y sociedad en la Hispania Visigoda. La "Vita Aemiliani" y el actual territorio riojano (siglo VI). Logroño, 1999, pp. 66 y s.

6. CASTELLANOS GARCÍA, S.: Calagurris tardoantigua..., pp. 40 y ss. 
no; de ahí que sus habitantes asuman dicho "martyrium", y todo el conjunto de la ciudad, como referencia de poder y "escenario de esperanza"7.

Por otro lado, a raíz de las excavaciones arqueológicas realizadas en el entorno de la actual catedral, Tudanca Casero y López de Calle Cámara consideran que esta hipótesis extrapola situaciones de otras ciudades altomedievales sin tener en cuenta la realidad topográfica de Calahorra. Además, al no existir otro dato acerca del baptisterio salvo el himno de Prudencio ${ }^{8}$, consideran a éste una recreación literaria "a posteriori" para justificar este emplazamiento y prestigiar la autoridad episcopal, elemento que permite a la ciudad continuar articulando el territorio circundante. Estos autores interpretan la ubicación excéntrica de la catedral calagurritana como una consecuencia de la falta de espacio en el interior del recinto amurallado (donde el abandono de las pautas urbanísticas romanas permite la utilización residencial de espacios públicos), de las exigencias higiénicas a la hora de localizar el cementerio adyacente al templo y de las posibilidades de comunicación ofrecidas por la cercanía del río y el mejor acceso al puente. De este modo, Calahorra experimentaría un proceso parecido al de otras urbes peninsulares como Zaragoza, Barcelona, Sevilla, Lugo, Tarragona, Sagunto, Mérida, Astorga, León o Porcuna, donde, al no haber sitio en un foro ocupado por viviendas, los conjuntos paleocristianos dan lugar a "suburbia" en zonas marginales".

Tenga dicho martirio un papel seminal o subsidiario respecto a esta transformación urbanística, no cabe duda de que la Calahorra tardoantigua consta de un núcleo principal amurallado en torno al actual Rasillo de San Francisco, protegido por la cerca bajoimperial o retraído dentro de los muros de la acrópolis del siglo I a. C., y, descendiendo este cerro, de un incipiente asentamiento, o "suburbium", junto a un centro religioso en la ribera del Cidacos. Lecuona no identifica la sede episcopal con este templo, pues ubica la catedral en la acrópolis amurallada del rasillo de San Francisco, donde Bujanda conjetura con la

7. ESPINOSA RUIZ, U.: Calagurris Iulia. Logroño, 1986, p. 23. CASTELLANOS GARCÍA, S.: Calagurris tardoantigua..., pp. 33 y s.

8. Las excavaciones realizadas en los años 1995 y 1996 sacan a la luz la mitad de una cisterna o depósito dentro de la necrópolis, iniciada en el siglo XII, junto al muro norte de la actual catedral. Resulta tentador interpretarlo como una piscina paleocristiana para bautismos por inmersión, quizás restos del primitivo baptisterio; no obstante, con más seguridad, esta cisterna estaría destinada al lavado de los cuerpos de los difuntos, ritual hispanogodo que perdura durante los siglos medievales. CENICEROS HERREROS, J.: "Calahorra. Excavación arqueológica en el muro norte de la catedral". Estrato. Revista Riojana de Arqueología, VIII (1997), p. 54.

9. TUDANCA CASERO, J. M.: Evolución socioeconómica del Alto y Medio Valle del Ebro en época bajoimperial romana. Logroño, 1997, pp. 31 y ss. TUDANCA CASERO, J. M. y LÓPEZ DE CALLE CÁMARA, C.: "Entorno urbanístico de la catedral de Calahorra. Apuntes para una valoración patrimonial". Investigación humanística y científica en La Rioja. Homenaje a Julio Luís Fernández Sevilla y Mayela Balmaseda Aróspide. Logroño, 2000, pp. 178-181 y 184-185. 
existencia de una iglesia visigoda precedente de la del Santo Sepulcro ${ }^{10}$. Lecuona lleva a esta conclusión al documentarse allí la existencia de la iglesia de San Salvador a partir de 1336, siendo ésta una advocación propia de templos catedralicios ${ }^{11}$. La relativa consistencia de estos argumentos y la citada rentabilización del lugar martirial por parte de la autoridad episcopal nos lleva a considerar el emplazamiento de la catedral visigoda en dicho "suburbium". Se trataría de una realidad similar a Gerona, Segóbriga y Toledo, cuyos "suburbia" se organizan en torno a un "martyrium" en honor de San Félix, en el primer caso, o a un templo catedralicio, en las otras dos poblaciones ${ }^{12}$.

\section{Calahorra en la historia de al-Andalus}

Tras ocupar Mūsà b. Nușayr el Valle del Ebro en el $714^{13}$, la inserción de Calahorra en el estado andalusí resulta muy confusa. Seguramente, sólo hubiese una ocupación militar de la parte más elevada del recinto amurallado. En un primer momento, los musulmanes huyen de las ciudades y se instalan en puntos fortificados, asentamientos rurales o urbes de nueva creación, buscando un ambiente más propicio para desarrollar su modo de vida y controlar un territorio donde se hallan en minoría ${ }^{14}$. Al igual que en otras comar-

10. LÓPEZ DOMECH, R.: Calahorra y su entorno histórico en el Archivo documental del Canónigo Fernando Bujanda (siglos XI-XV). Calahorra, 2005, p. 238.

11. Lecuona y Rodríguez de Lama remontan su existencia al siglo XI en razón de la presencia de un "Toto concilio de Sancti Salbatore" confirmando una operación en la vecina localidad de Azagra antes de la reconquista de Calahorra. LECUONA, M. de: "La catedral de Calahorra (notas histórico-arqueológicas)". Berceo, II (1947), p. 64. RODRíGUEZ Y RODRÍGUEZ DE LAMA, I.: Colección Diplomática...II, doc. 11. SAÍNZ RIPA, E. y HERNÁEZ IRUZUBIETA, V.: Documentación Calagurritana..., doc. 223.

12. La categoría catedralicia del monasterio toledano de San Cosme y San Damián, situado extramuros de la ciudad de Toledo, no es tan clara, aunque controla la sede episcopal durante el siglo VII, siendo el origen de cuatro prelados. GARCíA MORENO, L. A.: "La cristianización de la topografía de las ciudades de la península ibérica durante la antigüedad tardía". Archivo Español de Arqueología, L-LI (1977-78), pp. 319-321.

13. Ésta es la hipótesis admitida por la mayoría de los historiadores (Lévi Provençal, Sánchez Albornoz, Chalmeta y Senac) frente a Viguera, quien sostiene que la ocupación del alto Ebro fue obra de `Abd al-`Azìz uno o dos años después. SENAC, Ph.: "El dominio musulmán: Primeras investigaciones". Historia de la ciudad de Logroño, II: Edad Media. Logroño, 1994, p. 20. VIGUERA MOLINS, M. J.: Aragón musulmán. La presencia del Islam en el Valle del Ebro. Zaragoza, 1988, pp. 38 y s.

14. Esta conclusión se extrae de las coetáneas transformaciones urbanas del este peninsular y de los asentamientos rurales islámicos al norte del Ebro. LLOBREGAT, E. A.: "De la ciudad visigótica a la ciudad islámica en el este peninsular". Simposio internacional sobre la ciudad islámica. Ponencias y comunicaciones. Zaragoza, 1991, pp.186 y s. SÉNAC, Ph.: "Stratigraphie du peuplement musulman au nord de 'Ebre (VIIle-Xle siècles)". De la Tarraconaise à la Marche Supérieure d’al-Andalus (IVe-XIe siècle): les habitats ruraux. Toulouse, p. 64. 
cas vecinas ${ }^{15}$, la zona donde se incardina Calahorra se sometería a los invasores mediante un pacto con las oligarquías locales, continuando bajo el control del gobernador godo del valle medio del Ebro, el conde Casius, convertido al Islam, y de sus descendientes, los Banū Qāṣi ${ }^{16}$. Se configura así uno de los denominados "virreinatos" vasallos del estado cordobés, cuyo control se transmite de padres a hijos dentro de las élites locales, propios de los "țugūr al-Islām", o territorios fronterizos del Islam con los infieles. Al igual que los restantes linajes tagarinos ${ }^{17}$, los Banū Qāṣi evidencian una tendencia a la autonomía política y, en pos de ella, alternan su fidelidad al emirato cordobés con momentos de acercamiento a la dinastía pamplonesa de los Arista. Bajo este prisma hay que interpretar las expediciones militares lanzadas contra Calahorra por los emires 'Abd al-Raḥmān I y al-Hakam I. En el 781, 'Abd al-Raḥmān I toma la ciudad y, desde allí, conquista Viguera; poco después de subir al trono en el 796, al-Hakam I envía al general 'Abd al-Karīm b. Mugīt a ocupar y fortificar o saquear Calahorra, base para que su caballería penetre hacia el alto Valle del Ebro ${ }^{18}$. En la pri-

15. Este tipo de pactos se establece con los habitantes de Huesca, del valle del Cinca, del entorno de Zaragoza y del norte de Lérida. SÉNAC, Ph.: "Stratigraphie..., pp. 62 y s.

16. SOUTO LASALA, J.: "El noroeste de la frontera superior de Al-Andalus en época omeya: poblamiento y organización territorial". García Sánchez III "el de Nájera". Un rey y un reino en la Europa del siglo XI. XV Semana de Estudios Medievales de Nájera. Logroño, 2005, p. 254.

17. CHALMETA, P.: "El concepto de Tagr". La Marche Supérieure d'Al-Andalus et I'Occident Chrétien. Madrid, 1991, p. 26.

18. Corriente, Ali Makkī, Ruiz Girela y Vallvé traducen el texto de Ibn Hayyān como "acabó con sus recursos" o "la arrasó"; en cambio, Levi Provençal y García Gómez lo interpretan como "la guarneció con sus tropas". IBN HAYYĀN: Crónica de los emires Alhakam I y Abdarrahman II entre los años 796 y 847 (Almuqtabis II-1). Zaragoza, 2001, p. 24. VALLVÉ, J. y RUIZ GIRELA, F.: La primera década del reinado de Al-Hakam I, según el Muqtabis II, 1 de Ben Hayyan de Córdoba (m. 469 h./1076 J. C.). Madrid, 2003, p. 108. SOUTO LASALA, J. A.: "El noroeste de la frontera superior de al-Andalus en época omeya: Los datos de las fuentes geográficas e históricas, II". Boletín de la Asociación Española de Orientalistas, XXX (1994), p. 268. A esta expedición, acontecida poco después del 798, creemos que se refiere el siguiente párrafo de Rodrigo Jiménez de Rada: "Post hec, actis felicibus eleuatus, misit quendam de suis magnatibus Abdelcarim nomine cum suo exercitu Calagurram. Abdelcarim autem cum obsedisset aliquandiu Calagurram et eciam usque ad mare emissariis phalangibus plurima deuastaret, cum prede gloria copiosa in mittentis dominium est reuersus anno Arabum CC, regni autem Alhacam XVIIII". Aunque el arzobispo toledano sitúa esta campaña en el 814, no registramos ninguna expedición entonces y la acontecida dos años después no tiene como destino a Calahorra. LOZANO SÁNCHEZ, J.: Historia Arabvm de Rodrígo Jiménez de Rada. Sevilla, 1974, p. 40. LEVI PROVENÇAL, E.: Historia de España dirigida por Menéndez Pidal , IV: España musulmana hasta la caída del califato de Córdoba (711-1031). Madrid, 1967, pp. 113 y s.

Respecto a estas acciones militares en torno a Calahorra, hay mucha confusión. Se amplía el número de expediciones simplemente por confusiones en las fechas; en otras ocasiones, se incluye a Calahorra en el curso de campañas que, aunque documentadas, no consta que llegasen hasta la ciudad del Cidacos. Así, el padre Lucas la menciona entre las conquistas del monarca asturiano Alfonso I en el 750, hace que Alfonso II levante su asedio en el curso de su campaña del 815 e, incluso, la incluye entre las localidades recuperadas por Ramiro I tras la legendaria batalla de 
mera de estas campañas, el Fath al-Andalus describe a los habitantes de Calahorra como "infieles" distintos de los vascones, con los que hacen causa común; de ahí que Manzano Moreno vea en esta denominación una referencia temprana a los Banū Qāșịi' . De este modo, a lo largo de la siguiente centuria, Calahorra continúa integrando los dominios de este linaje, asistiendo a sus alternativos periodos de fidelidad y de enfrentamiento con los emires omeyas, así como a las disputas internas de los sucesores de Mūsà b. Mūsà, principal figura de los Banū Qāṣīiñ .

La fundación de Tudela a principios del siglo IX respondería al objetivo, no sólo de afianzar la presencia musulmana frente a peligros exteriores, sino también de controlar dichas fuerzas centrífugas. A partir de entonces, Calahorra queda subordinada a esta nueva "madīna", integrando su término o "min a māl" 21 . De este modo, al igual que otras localidades de la actual Rioja como Nájera, Viguera, Arnedo y Alfaro, Calahorra figura como un "hișn", o posición fortificada, dirigida por un "wālı", desde donde se controla un pequeño territorio ("iqlīm") de la Marca Superior de Al-Andalus ("Tagr-al-a 'à")"22. En opinión de Zozaya, el "Hiṣn Qalahurra" es una de las posiciones defensivas dispuestas de modo concéntrico respecto del núcleo central ubicado en Tudela; asimismo, desde Calahorra partiría una avanzadilla hacia La Rioja Alta siguiendo las calzadas romanas TarracoAsturica (Nájera, Grañón, Ibrillos) y del valle del Iregua (Albelda, Viguera) ${ }^{23}$.

Clavijo en el 844 ó 849. De igual modo, Saínz Ripa, no sólo se hace eco de estas imprecisiones, sino que, siguiendo a Gutiérrez de Achútegui, habla de la toma de Calahorra por la razzia fugaz de `Ubayd Allāh b. Uthman en el 791, hecho que no corrobora ninguna fuente. SAN JUAN DE LA CRUZ, L. de: Historia de Calahorra y sus glorias. Valencia, 1925, pp. 221 y ss. SAÍNZ RIPA, E.: Sedes Episcopales de La Rioja, I (Siglos IV-XIII). Logroño, 1994, pp. 138 y ss. Otras veces, se trata de una mala interpretación de la documentación; así, Moret, al leer un lindero llamado "Ennecho rege" en un documento calagurritano de 1145, habla de una supuesta toma de Calahorra por el monarca pamplonés Iñigo Jiménez en el 735. MORET, J. de: Anales del Reino de Navarra, I. Pamplona, 1987, p. 256.

19. MANZANO MORENO, E.: La Frontera de al-Andalus en época de los omeyas. Madrid, 1991, pp. 114 y s.

20. En el 842, Mūsà b. Mūsà y García Iñiguez de Pamplona derrotan a Hārith b. Bazi cuando éste atraviesa el Ebro desde Calahorra a San Adrián en la Ilamada batalla de Palma. En el 872, Lūbb b. Mūsà es capturado cerca de Calahorra por sus hermanos, quienes le obligan a devolver el castillo de Arnedo. Años más tarde, en el 883, su hijo Muḥammad b. Lūbb vence en las proximidades de Calahorra a su tío Ismā’îl b. Mūsà y a sus primos Ismā’îl y Lūbb b. Furtūn. Quizás también fue en el valle de Calahorra donde Muhammad b. `Abd Allāh apresó y asesinó a Muṭarrif b. Muhammad b. Lūbb en el año 916. IBN ḤAYYĀN: Crónica..., p. 309. DE LA GRANJA, F.: "La Marca Superior en la obra de Al-Udrí". Estudios de Edad Media de la Corona de Aragón, VIII (1967), pp. 473, 476 y 484. CAÑADA JUSTE, A.: "Los Banu Qasi (724-924)". Príncipe de Viana, CLVIII-CILX (1980), pp. 16, 48, 56, 58, 80, 83 y 86.

21. SOUTO LASALA, J.: "EI noroeste..., p. 258 y 260.

22. Ibidem, p. 260. SENAC, Ph.: "El dominio musulmán...", pp. 20 y s.

23. ZOZAYA, J.: "Notas sobre las comunicaciones en el al-Andalus omeya". Arqueología Medieval Española. II Congreso, I. Madrid, 1987, p. 225. MANZANO MORENO, E.: La Frontera..., p. 118. SCALES, P. C.: "La red militar en el Tagr-al-a là en los siglos X y XI. Análisis e índice topográfico". Boletín de Arqueología Medieval, IV (1990), pp. 13, 122 y s. 
Retomando la denominación de "infieles" aplicada por las crónicas islámicas a los calagurritanos de finales del siglo VIII, intuimos que, bajo el gobierno de la citada élite muladí, la mayoría de la población de Calahorra conserva la cultura y la fe cristianas; situación generalizada en todo el Valle del Ebro hasta mediados del siglo $\mathrm{X}^{24}$. El respeto al culto cristiano sería uno de los acuerdos del supuesto pacto de sumisión y, en consecuencia, los calagurritanos cuentan con su catedral, que no será destruida hasta el 932, y quizás con la permanencia de los obispos. Uno de estos podría ser Recaredo, obispo de Calahorra que confirma la dotación fundacional de la iglesia de San Salvador de Oviedo en el 812 25 ; no obstante, ignoramos si este prelado reside en Oviedo o se desplaza desde la ciudad del Cidacos para asistir a dicho acontecimiento. A pesar de esta tolerancia, parte de la población calagurritana huye, desde la inestabilidad provocada por las fluctuantes alianzas de los Banū Qāșī, hacia la mayor seguridad ofrecida por los núcleos de resistencia cristianos del alto Ebro; testigos de este movimiento demográfico son las advocaciones de los mártires San Emeterio y San Celedonio documentadas en esta zona a principios del siglo IX ${ }^{26}$.

El ascenso de Sancho Garcés I al trono pamplonés en el 905, inaugurando la dinastía de los Abarca o Jimeno, y su subsiguiente alianza con el monarca leonés acentúan la presión cristiana sobre las posiciones islámicas del alto Ebro. Los más de cien años de colaboración de los Banū Qāṣi con los Arista han impedido el desarrollo de un eficaz tejido defensivo en una frontera configurada a base de las zonas de influencia de los distintos linajes, donde la presencia del poder cordobés sólo se deja sentir durante las esporádicas expedi-

24. SÉNAC, Ph.: "Stratigraphie..., pp. 63 y ss. Existe el testimonio epigráfico de la fundación de un monasterio mozárabe hacia el 869 en Arnedillo, localidad situada aguas arriba del Cidacos. UBIETO ARTETA, A.: "Sobre la reconquista de La Rioja por pamploneses". Homenaje a José María Lacarra. Príncipe de Viana, XLVII (1986), pp. 755-763. En el 912, al llegar al poder `Abd al-Raḥmān III, sólo un 25\% de la población de al-Andalus era musulmana. BULLIET, R. W.: Conversión to Islam in the Medieval Period: An Essay in Quantitative History. Cambridge, 1979 (citado por SENAC, Ph.: "El dominio musulmán..., p. 23).

25. Además, existe una dudosa serie de obispos calagurritanos durante los siglos VIII y IX. La inicia Félix, confirmante del XVII Concilio de Toledo (695) que, según una leyenda recogida por el padre Lucas, se refugiaría en el Camero Viejo ante la invasión musulmana. Y forman parte de ella Teodomiro y Severo citados en dos diplomas falsos fechados en el 792 y el 877, respectivamente, y Bivere, que figura en un documento emilianense del 871, pero in explicitar su sede, pudiendo ser prelado de Valpuesta o Álava. SAN JUAN DE LA CRUZ, L. de: Historia..., pp. 218 y ss. SAÍNZ RIPA, E.: Sedes..., I, pp. 142 y ss. UBIETO ARTETA, A.: “Episcopologio de Álava". Hispania Sacra, VI (1953), p. 39.

26. Desde el año 800 se documenta un monasterio dedicado a estos mártires en Taranco y, cuatro años más tarde, se cita el término de San Emeterio y San Celedonio en Vapuesta. SAÍNZ RIPA, E.: Sedes..., I, p. 144. UBIETO ARTETA, A.: Cartulario de San Millán de La Cogolla (7591076). Valencia, 1976, docs. 2-5, 17, 18, 131 y 183. 
ciones militares ${ }^{27}$. Esta circunstancia facilita los avances de pamploneses y leoneses y, en consecuencia, Calahorra cambia de manos al menos en nueve ocasiones. En el 907, Sancho Garcés I la ocupa aprovechando la muerte de Lūbb b. Muḥammad, uno de los últimos Banū Qāșīin . Siete años después, en respuesta a la incursión del monarca pamplonés por el valle del Alhama, 'Abd Allāh b. Muhammad, hermano del fallecido, recupera la ciudad ${ }^{29}$. No obstante, el declive de este linaje muladí permite que Sancho Garcés conquiste de nuevo Calahorra en el 917 ó 918, cuando dirige una campaña contra Tudela, ciudad defendida por Muhammad b. 'Abd Allāh, su último señor Banū Qāṣ̄īio .

La escasa eficacia de los Banū Qāṣī frente a la presión cristiana reclama la intervención directa del poder cordobés. En el 920, Muḥammad b. 'Abd Allāh avanza desde Tudela y destruye Calahorra, abandonada por los cristianos, mientras el emir 'Abd al-Raḥmān III se dirige contra los pamploneses dando lugar a la batalla de Muez ${ }^{31}$. Hacia el 922, Sancho Garcés I recupera de nuevo Calahorra, a la vez que reconquista definitivamente la Rioja Alta; dos años después, tras volver a tomar la ciudad, dicho emir decide arrasarla y abandonarla, retrasando su posición más avanzada hasta Valtierra, lugar más defendible ${ }^{32}$. Aprovechando el repliegue cordobés, los cristianos recuperan Calahorra junto a todo el valle del $\operatorname{Cidacos}^{33}$. Debieron existir más alternancias, pues en el 932 tiene lugar la destrucción de la iglesia calagurritana por "Almundus" ${ }^{34}$,

27. MANZANO MORENO, E.: La Frontera..., p. 118.

28. IBN IDARI: Histoire de l'Afrique et de l'Espagne intitulée Al Bayano'l Mogrib, Argel, 1904, tomo II, p. 276.

29. VIGUERA, M. J. y CORRIENTE, F.: Crónica del califa Abdarramán III an’ Nasir entre los años 912 y 942 (al-Muqtabis V) de Ibn Hayyan de Córdoba. Zaragoza, 1981, p. 85. VIGUERA MOLINS, J. M.: Aragón..., pp. 112 y 117.

30. VIGUERA MOLINS, J. M.: Aragón..., pp. 117 y ss. CAÑADA JUSTE, A.: "Los Banu Qasi..., p. 81.

31. VIGUERA, M. J. y CORRIENTE, F.: Crónica del califa Abdarramán III..., pp. 130 y 131.

32. Ibidem, p. 148 y 151.

33. En el 958 figura Blasco Lihurt como "possidente in Arneto". Entre los años 943 y 950, el presbítero Hermenegildo dona a San Martín de Albelda todas sus heredades en Préjano, Cervera y Cornago. El "concilio de Miromnes" (Santa Eulalia) confirma la donación de Abgamira a ese mismo monasterio en el 978. UBIETO ARTETA, A.: Cartulario de Albelda. Zaragoza, 1981, docs. 18,23 y 27.

34. Siguiendo a Risco, Sáinz Ripa lo relaciona con la toma de la ciudad en el 920. SAINZ RIPA, E.: Sedes..., I, pp. 163 y s. Llorente sitúa este hecho en el 929, considerándolo una represalia por la victoria cristiana en la batalla de Simancas. LLORENTE, J. A.: Apuntes históricos sobre algunas obras antiguas de arquitectura de la ciudad de Calahorra y su iglesia catedral. 1881. Manuscrito conservado en el Archivo del Instituto de Estudios Riojanos, p. 28. Senac identifica esta destrucción con la provocada por 'Abd al-Raḥmān III ocho años antes. SENAC, Ph.: "El dominio musulmán..., p. 28. Sin embargo, el documento conservado en el Archivo Catedral de Calahorra consigna este acontecimiento en "Era DCCCC. LXX". RODRÍGUEZ Y RODRÍGUEZ DE LAMA, I.: Colección Diplomática Medieval de La Rioja, II (923-1168). Logroño, 1992, doc. 77. 
hasta que Gālib, en nombre del califa al-Hakam II, la conquiste de nuevo en el $968^{35}$. Entonces, los visires-cadíes Gālib b. 'Abd al-Raḥmān y Sa'īd b. alHakam al-Safarī acampan frente a Calahorra, reconstruyen ("banà") su cinturón ("ḥizām") con siete torres, añaden ("zāfū $f \bar{I}^{\prime \prime}$ ) la octava torre en lo más alto de la cima e instalan en ella una guarnición (" askar") $)^{36}$. Esta repoblación y fortificación de Calahorra se inserta en una nueva estrategia cordobesa en pos de implantar una organización más clara de los "țugūr" ${ }^{37}$. Es decir, el poder califal pretende articular un sistema fronterizo más eficaz apoyado en núcleos cuya población y/o fortificación promueve; se trataría de un adelanto de la política de nueva colonización generalizada durante el periodo amirín ${ }^{38}$. Aunque en el caso de Calahorra consideramos primordiales las motivaciones defensivas, en estas fortificaciones y fundaciones también influiría el deseo califal de ejercer un control más efectivo del territorio que permitiese la imposición tributaria ${ }^{39}$.

Estas iniciativas colonizadoras en los "țugūr" traen consigo una mayor islamización y arabización de dichos territorios, dinámicas que se aprecian al norte del Ebro desde la instauración del Califato de Córdoba ${ }^{40}$. Calahorra no supone una excepción al respecto. Las sucesivas destrucciones y despoblaciones

35. MACHADO MOURET, O.: "Historia de los árabes de España por Ibn Jaldún". Cuadernos de Historia de España, XLVII-XLVIII (1968), p. 355.

36. SOUTO LASALA, J. A.: "El noroeste de la frontera..., II, pp. 268 y s. "Las conquistas de Al-Hakam II y de sus generales alcanzaron extraordinaria magnitud en los países fronterizos de todos los contornos, siendo una de las más grandes la toma de Qalahorra, en tierras de los Vascones, por mano de Galib, a la que repobló, preocupándose por su prosperidad". Ibidem, p. 355.

37. En esta línea, documentamos las murallas de Barbastro y Huesca, así como nuevas fortalezas o "ḥușūn" en el entorno rural de esta localidad, a principios del siglo X, la repoblación de Évora en el 914 ó 915, el amurallamiento de Olite poco después del 925, la construcción de la alcazaba de Talavera en el 937, la fortificación de Catalifa y Saltan en el 940 ó 941, los desvelos de 'Abd al-Raḥmān III por taponar el alto Duero mediante la construcción del castillo de Gormaz y el refuerzo de las fortalezas de Atienza, Medinaceli, Almazán, Berlanga y Osma,... SÉNAC, Ph.: "Stratigraphie..., pp. 65 y s. CABAÑERO SUBIZA, B.: "La madina islámica de Olite..., p. 306. CHALMETA, P.: "EI concepto..., p. 21. MANZANO MORENO, E.: La Frontera..., pp. 381 y s. CRUZ HERNÁNDEZ, M.: El Islam de Al-Andalus: historia y estructura de su realidad social. Madrid, 1996, p. 356. MAZZOLI-GUINTARD, Ch.: Ciudades de Al-Andalus: España y Portugal en la época musulmana (siglos VIII-XV). Granada, 2000, pp. 255 y s.

38. ERITJA CIURÓ, X.: De l'Almunia a la Turris..., pp. 32 y s. En el momento de su muerte, Almanzor describe estas iniciativas colonizadoras en los territorios fronterizos: "Cuando conquisté las tierras de los cristianos y sus fortalezas las repoblé (y avituallé) con los medios de subsistencia de cada lugar y las sujeté con ellas hasta que resultaron favorables completamente. Las uní al país de los musulmanes y fortifiqué poderosamente y fue continua la prosperidad". MAILLO SALGADO, F.: Historia de al-Andalus de Ibn Al-Kardabūs. Barcelona, 1986, p. 86.

39. Este sería el objetivo básico de las fundaciones de Madrid, Salamanca y Alcalá de Henares, en el siglo IX, y de la citada fortificación de Catalifa en el 940. MARTíN VISO, I.: "Castillos, poder feudal y reorganización espacial en la Transierra madrileña (siglos XII-XIII)". Espacio, Tiempo y Forma. Historia Medieval, XIII (2000), pp. 182 y ss.

40. SÉNAC, Ph.: "Stratigraphie..., p. 67. 
sufridas por la ciudad acabarían con la comunidad cristiana; un fragmento de crónica conservado en el archivo catedralicio relata como "...destruxit Almundus ecclesiam Calagurritane sedis" en el año 93241. La repoblación llevada a cabo por Gālib después del 968 supondría un importante aporte demográfico claramente islámico; incluso, es posible que recogiese a fugitivos o cautivos huidos ante el avance cristiano sobre La Rioja Alta. Esta posibilidad, apuntada por Sénac, se halla dentro de las funciones propias de los asentamientos tagarinos; así, al reconstruir los castillos de Viguera y "Gotior" a finales del siglo IX, uno de los objetivos del Banū Qāṣi Muhammad b. Lūbb es que sirvan de refugio para los prisioneros evadidos ${ }^{42}$. Además de este contingente musulmán, la ciudad también albergaría población hebrea a tenor de la referencia al "ritu judaico" contenida en la dotación fundacional de García Sánchez III a la sede calagurritana en $1045^{43}$.

Recordemos que hasta la Ilegada de Gālib, Calahorra resulta destruida tres veces durante la primera mitad del siglo X: en el 920 por el gobernador de Tudela Muḥammad b. Lubb"4, en el 924 a manos del el emir 'Abd al-Raḥmān III, quien posteriormente la abandona ${ }^{45}$, y, en el 932, al acabar "Almundus" con la iglesia cristiana ${ }^{46}$. Tan intensas son estas destrucciones que, en la primavera del 934, cuando el ya califa 'Abd al-Raḥmān III recibe a la reina Toda de Pamplona, Calahorra, lugar de este encuentro, se reduce sólo a una "mahalla" o campamento temporal de las tropas cordobesas ${ }^{47}$. Tal cantidad de conquistas, reconquistas y saqueos en apenas medio siglo avalan la opinión de Souto Lasala, para quien Calahorra es sólo una plaza con discontinua ocupación militar, cuyos momentos de abandono son aprovechados por el enemigo para ocuparla ${ }^{48}$.

Sin embargo, esto cambia a partir del 968, cuando sea repoblada y fortificada por Gālib. A partir de entonces, la presencia militar se torna continua y Calahorra confirma su carácter de "hiṣnn" o posición fortificada, tal y como es citada en los textos árabes. Mientras Aḥmad al-Rāzī (889-955) simplemente la menciona como villa del término de Tudela ${ }^{49}$, las posteriores obras de Al-'Udrī

41. RODRÍGUEZ Y RODRÍGUEZ DE LAMA, I.: Colección Diplomática...II, doc. 77.

42. SENAC, Ph.: "El dominio musulmán..., p. 24. CHALMETA, P.: "El concepto..., p. 25.

43. "Insuper pro tanta presumptione tria milia auri talenta regie severitati persolvat et quod usurpaverit ecclesie, Ponticifique ac clero in duplum ritu judaico reddat". RODRÍGUEZ Y RODRÍGUEZ DE LAMA, I.: Colección Diplomática...II, doc. 6.

44. "...los musulmanes la derruyesen de consuno, cosa en que se esforzaron hasta hacerla desaparecer y dejarla como si no hubiera sido próspera el día anterior: destruyeron incluso todos sus alrededores". VIGUERA, M. J. y CORRIENTE, F.: Crónica del califa Abdarramán III..., pp. 130 y s.

45. Ibidem, pp. 148 y 151.

46. RODRÍGUEZ Y RODRÍGUEZ DE LAMA, I.: Colección Diplomática...II, doc. 77.

47. VIGUERA, M. J. y CORRIENTE, F.: Crónica del califa Abdarramán III..., p. 252.

48. SOUTO LASALA, J. A.: "El noroeste de la frontera..., II, p. 268.

49. CATALÁN, D. y DE ANDRÉS, M. S.: Crónica del moro Rasis. Madrid, 1975, p. 53. 
(1002-1085), Al-Kardabūs (segunda mitad del siglo XII) e Ibn `Idārī (siglos XIII y XIV) ya hablan del "hiṣn Qalahurra" dentro de la demarcación tudelana ${ }^{50}$. Ignoramos si la voz "Qalahurra" deriva del nombre romano de "Calagurris" o de la expresión árabe "qal'a hurra" cuyo significado, "baluarte defensivo de gran importancia que protege determinados puntos estratégicos" ${ }^{\prime \prime 1}$, coincide con la realidad física e histórica de la ciudad durante este periodo. Estos últimos ochenta años de la Calahorra islámica se caracterizan por una estabilidad fronteriza que permite su desarrollo urbano, dando lugar a un arrabal, y acelera el citado proceso de islamización.

A pesar de su reorganización en época califal, la Marca Superior de al-Andalus sigue apoyándose en pactos con élites locales (los BanūTuŷībī de Zaragoza son un buen ejemplo) y, por consiguiente, no existe un estado centralizado que controle la frontera5"; de ahí que, tras la "fitna", o desintegración del califato, Calahorra pase a depender de las taifas tuŷībī y hūdī de Zaragoza a partir de 1018 y de 1039, respectivamente. Estos poderes locales, ya plenamente autónomos, no pueden hacer frente a la presión militar de los reinos cristianos; así, las vecinas localidades de Autol y Azagra cuentan con un tenente pamplonés en torno al $1036^{53}$. Además, dichas taifas van cayendo en el juego del enfrentamiento mutuo y de la sumisión económica a pamploneses y castellanos mediante el pago de parias. La competencia entre estos monarcas cristianos por percibir dicho caudal tributario supone la causa inmediata de la definitiva reconquista cristiana de Calahorra. Fernando I de Castilla protege a Sulaymān b. Hūd, rey de la Taifa de Zaragoza, mientras García Garcés III, rey de Pamplona y Nájera, hace lo propio con el monarca toledano Yahyā b. Dhī-I-Nūn. En represalia por el ataque de Ibn Hūd contra Medinacelli, ciudad de Ibn Dhī-I-Nūn, don García irrumpe en la taifa zaragozana tomando la ciudad de Calahorra el 30 de abril de $1045^{54}$.

\section{Estructura y funciones de la Calahorra islámica}

Una vez contextualizada Calahorra dentro de la historia de al-Andalus, intentamos vislumbrar las líneas maestras de su organización socioeconómica,

50. SOUTO LASALA, J. A.: "El noroeste de la frontera..., II, pp. 164, 178 y 241. MAILLO SALGADO, F.: Historia de al-Andalus..., p. 86. Al narrar el momento de su reconquista, denomina a Calahorra "fortaleza...de la frontera de Tudela". La caída del Califato de Córdoba y los Reyes de Taifas (al-Bayan al-Mugrib) de Idn 'Idari. Salamanca, 1993, p. 233.

51. "No ha podido establecerse la etimología Calagurris $>$ Qalahurra $>$ Calahorra". TERES, E. y VIGUERA, M. J.: "Sobre las Calahorras". Al-Qantara, II (1981), pp. 265-275.

52. MANZANO MORENO, E.: La Frontera..., pp. 381 y s.

53. "senior Lop Fortunionis de Ipia et de Abtol". UBIETO ARTETA, A.: "Estudios en torno a la división del Reino..., p. 227. "senior Eximino Garzeiz Azekra, et Kallahorra Sarracinos". RODRÍGUEZ Y RODRÍGUEZ DE LAMA, I.: Colección Diplomática...II, doc. 11.

54. MAILLO SALGADO, F.: La caída del Califato..., pp. 232 y s. TURK, A.: El reino de Zaragoza en el siglo XI de Cristo (V de la Hégira). Madrid, 1978, pp. 70 y ss. 
tanto del espacio de la propia ciudad como del entorno rural articulado en torno a ella. En líneas generales, y siempre en función de los datos obtenidos, intentamos aplicar el modelo enunciado por Mikel de Epalza ${ }^{55}$. Así, establecemos un espacio urbano, plenamente humano y definido por la muralla. A su alrededor, diferenciamos un entorno humanizado, el Ilamado espacio periurbano ("dawāhi"), dedicado tanto a actividades económicas de producción (agricultura intensiva de regadío), transformación (molinos, industrias polucionantes) e intercambio (mercado de productos perecederos) como a funciones religiosas (cementerios) y residenciales (viviendas rurales, palacios de recreo). Y, por último, nos encontramos con el campo abierto que acoge las vías de comunicación, los sistemas militares de vigilancia y defensa, así como los terrenos de pastoreo, agricultura extensiva y de actividades predatorias y extractivas (explotación forestal, caza, pesca, minería,...).

\subsection{Espacios y funciones urbanas}

Los datos documentales y topográficos nos invitan a establecer una dicotomía de espacios urbanos en la Calahorra islámica: un "hiṣn" militar, aclimatado a la coyuntura fronteriza, centro de control territorial y recaudación tributaria, más un arrabal que, desarrollado al calor de la estabilidad fronteriza vivida entre el 968 y el 1045, concentra las actividades de intercambio y transformación de la producción agraria. Pero, ante todo, hemos de ser prudentes, la documentación inmediatamente posterior a la reconquista se centra en el arrabal, donde se ubica la catedral y el recuerdo de los santos mártires, centro neurálgico y espiritual de la ciudad cristiana. A consecuencia de ello, nos transmite una imagen real, pero sesgada por el protagonismo de esta colación respecto al resto de la urbe.

\subsubsection{El "Hiṣn Qalahurra"}

La coyuntura de inseguridad sufrida por Calahorra desde el momento hispanogodo daría lugar una reducción de su hábitat a posiciones más defendibles en torno al actual Rasillo de San Francisco. Esta localización fortificada constituía el "ḥiṣn Qalahurra", mencionado en las fuentes árabes y reconstruido por Gālib. Ya hemos adelantado que, frente a la opinión de otros autores ${ }^{56}$, y a la espera de excavaciones arqueológicas, Iguácel de la Cruz identifica los restos de la plaza del Raso y la calle Carreteros con una muralla levantada por Mūsà b. Nuṣayr hacia el $714^{57}$. La oposición de la puerta Nueva, abierta en esta cer-

55. EPALZA, M. de: "Un modelo operativo de urbanismo musulmán". Sharq Al-Andalus. Estudios Árabes, II (1985), pp. 137-149. "Espacios y funciones de la ciudad árabe". Simposio internacional sobre la ciudad islámica. Ponencias y comunicaciones. Zaragoza, 1991, pp. 10 y ss.

56. Ver nota 3.

57. IGUÁCEL DE LA CRUZ, P.: “El trazado..., p. 48. 
ca, frente a la puerta Vieja, perteneciente al recinto bajoimperial, así como la existencia de una necrópolis medieval situada a extramuros en la calle Sol, son argumentos de peso ofrecidos por esta autora para considerarla una cerca de la misma época. Además, este tramo de muralla pudo estar ya construido antes del 1095, año de la primera mención al "barrio de Sancti Andres"58, pues los límites septentrionales de esta colación coinciden con su trazado, según la demarcación parroquial vigente hasta $1825^{59}$. Sin embargo, pudo erigirse en otros momentos anteriores a esta fecha: durante el periodo visigodo, justo después de la reconquista cristiana en el 1045 o tras la toma de la ciudad por Gālib en el 968. A expensas de las conclusiones que pueda aportar el estudio arqueológico de los restos todavía conservados, nos inclinamos por esta última cronología, pues es la única que cuenta con respaldo en las crónicas árabes. Recordemos que Gālib reconstruye un recinto amurallado compuesto por ocho torres. Podríamos identificar algunas de ellas con los torreones del Portillo de la Rosa, de la calle La Enramada, de la calle Carreteros, de la torre-campanario de Santiago, de doña Juana o de la Matrona y del Ayuntamiento, alineados de este a oeste en esta cerca; mientras que la octava torre, situada en el lugar más elevado, se correspondería con la torre del Sequeral en el actual Rasillo de San Francisco, cuya base se remonta a época romana ${ }^{60}$. La abundancia de torres en el muro norte del conjunto amurallado resulta lógica al tratarse de la zona más accesible a la meseta, es decir, la que ofrece menos defensa natural y, por tanto, requiere una mayor fortificación.

Hoy en día, sólo se conservan restos de dos de estas torres, las del Portillo de la Rosa y de la calle La Enrramada, así como fotografías del torreón del Ayuntamiento; sin embargo, aun haciendo uso de los testimonios documentales estudiados por Andrés Hurtado, no resulta fácil confirmar el origen califal de esta cerca. Los dos torreones conservados presentan un aparejo de mampostería con sillares en las esquinas, mientras los muros del ya desaparecido torreón del Ayuntamiento eran de "argamasa romana" con aparejo de mampostería ${ }^{61}$. Aunque podemos aducir la escasez de piedra en el entorno de Calahorra, todos estos materiales resultan diferentes de los sillares almohadillados, generalmen-

58. RODRÍGUEZ Y RODRÍGUEZ DE LAMA, I.: Colección Diplomática...II, doc. 42.

59. "... la Calle de la Enrramada, desde la casa de don Emeterio Miranda y Rodruejo por una cera, y por otra la casa del Vínculo de D. Jacinto Arenzana hasta el Portillo llamado de la Rosa, sin salir afuera;...". BUJANDA, F.: "Demarcación parroquial de Calahorra". Berceo, XXI (1951), p. 545.

60. En la actualidad, se conserva su base datada en el siglo I a. C.; está formada por tres tirantes de sillería en su interior, recubiertos de argamasa al exterior. EQUIPO CALAGURRIS IULIA: "El proyecto..., pp. 15 y ss.

61. Gutiérrez Achútegui considera el aparejo de mampostería del torreón del ayuntamiento como resultado de la remodelación realizada en 1507 a instancias de Juana I de Castilla. ANDRÉS HURTADO, G.: "Los torreones..., pp. 44 y 49. 
te dispuestos a soga, presentes en otras fortificaciones islámicas de la décima centuria en el Valle del Ebro ${ }^{62}$. El carácter macizo del torreón del Portillo de la Rosa, cuyo interior se encuentra relleno de tapial, o delata un arcaísmo o nos remite a antes del momento califal. Estas torres cuadradas y macizas fueron habituales en la frontera superior de al-Andalus hasta al menos el 920, siendo adoptado el modelo de torre hueca progresivamente después de esa fecha; con cierto retraso, los castillos del reino de Pamplona-Nájera experimentan una evolución desde la torre cuadrada y maciza hacia la circular y hueca, así como del tapial y la argamasa a la sillería ${ }^{63}$. En cuanto a su anchura, el torreón de doña Juana y, en menor medida, el situado en la calle La Enramada se hallan cercanos a los 4,50 metros habituales en las torres exteriores de otros recintos andalusíes como los de Medina Azahara, Talavera de la Reina, Huesca, Olite, Mérida y de la Puerta de la Vega en Madrid ${ }^{64}$. Asimismo, las excesivas dimensiones del torreón del Portillo de la Rosa (8,75 metros) y de la torre del Ayuntamiento (6,60 metros) podrían deberse a su localización en las esquinas del perímetro ${ }^{65}$. La proximidad de la torre-campanario de Santiago con la de doña Juana o de la Matrona se explicaría en función de la presencia del "baluarte de la Puerta Nueba" en la primera de ellas ${ }^{66}$; disposición similar, entre otras, a la puertas de la muralla omeyas de Ágreda y al posible antecedente islámico de la Puerta del Chapitel de Olite ${ }^{67}$.

62. Así ocurre en Olite, Tudela, Borja, Huesca, Balaguer,... CABAÑERO SUBIZA, B.: "La madina islámica de Olite (Navarra): claves para el estudio de su conjunto amurallado". Simposio internacional sobre la ciudad islámica. Ponencias y comunicaciones. Zaragoza, 1991, pp. 311 y ss.

63. Este tipo de torre hueca es el existente en la cerca califal de Olite. Ibidem, p. 306. Ya avanzado el siglo X, el castillo de Arnedo presenta la novedad de la torre circular, pero con el arcaísmo de su carácter macizo. A finales de esta centuría, el castillo de Nájera cuenta con construcciones realizadas en sillería. También es posible que nos encontremos ante dos momentos constructivos; en la fortaleza de Milagro (Navarra) existe una torre islámica cuadrada de tapial forrada posteriormente por otra construida con un encofrado a base de piedra y argamasa. CABAÑERO SUBIZA, B.: "La defensa del reino de Pamplona-Nájera en el siglo X. Materiales para el estudio de la evolución de los castillos". La marche superiéure d'al-Anmdalus et l'Occident chrétien. Madrid, 1991, pp. 105 y 112. ZOZAYA, J.: "Islámic fortifications in Spain: some aspects". Papers in Iberian Archaelogy, B.A.R. International Series 193. Oxford, 1984, pp. 636-673.

64. Las torres de estas murallas cuentan con una anchura entre 4,36 y 4,85 metros. CABAÑERO SUBIZA, B.: "La madina islámica de Olite..., p. 313. La anchura de la torre de la calle La Enrramada es de 5,60 metros; mientras, las dimensiones del torreón de doña Juana oscilan entre los 4,16 y 4,41 metros, calculados en 1778, y los 5,52 metros calculados en 1878, quizás a consecuencia de un recrecimiento posterior. ANDRÉS HURTADO, G.: "Los torreones..., p. 44,47 y s.

65. ANDRÉS HURTADO, G.: "Los torreones..., pp. 44 y 50. Así ocurre con las torres III (6,40 metros) y VIII (7,34 metros) de la fortificación de Olite y la torre cuadrangular de la muralla de Murcia (7 metros), aunque este último recinto data del siglo XII. CABAÑERO SUBIZA, B.: "La madina islámica de Olite..., pp. 308 y 311.

66. ANDRÉS HURTADO, G.: "Los torreones..., p. 46. MATEOS GIL, A. J.: La Iglesia de Santiago el Real de Calahorra (1500-1800). Logroño, 1991, p. 25.

67. CABAÑERO SUBIZA, B.: "La madina islámica de Olite..., pp. 308 y s. 
Dentro de la zona elevada, el recinto de la primitiva acrópolis altoimperial, en el actual Rasillo de San Francisco, denominado por la documentación latina "castella calagurritano", haría las veces de alcazaba, albergando el alcázar o "palacium regis" ${ }^{\prime 68}$. Este espacio cumple las misiones propias de un "hiṣn", es decir, la defensa del territorio circundante y su control mediante la imposición del tributo. En una fecha muy tardía, en el año 1356, el mudéjar calagurritano Mahoma Navarrero, y su mujer Marúm, entregan a las iglesias de Santiago y San Andrés una viña a cambio de unas casas situadas en el castillo calagurritano junto a la mezquita ${ }^{69}$. Este templo respondería más a la realidad de la población mudéjar en el siglo XIV que a la Calahorra islámica. No obstante, nos atrevemos a conjeturar la existencia de un oratorio musulmán en este castillo, la localización más céntrica y segura para albergar dicho templo; se correspondería con la iglesia del Santo Sepulcro, documentada poco después de la reconquista, concretamente en $1052^{70}$. Es posible que la población hebrea también residiese en este lugar, donde se ubica la judería en época cristiana, no siendo extraña en las ciudades andalusíes la concentración de la población judía en espacios intramuros ${ }^{71}$.

Fuera del castillo, carecemos totalmente de información acerca del espacio contenido por la supuesta cerca de Gālib. Seguramente albergase viviendas, como podría indicarlo el trazado intrincado del callejero, pero la única noticia que podría referirse a sus habitantes de este espacio es la donación de unas casas situadas en el barrio de San Andrés por parte de María, hija de Alcambiel, en 1095. El haber recibido dichos inmuebles "de parentibus nostris", junto a la etimología árabe del nombre de su progenitor, nos permite sugerir la posibilidad de remontar su ocupación a época islámica ${ }^{72}$.

68. En 1143, la catedral calagurritana entrega al monasterio de Santa María de Nájera un "solare in castella calagurritano, iuxtam palacium regis, ante ecclesiam Sancti Sepulcri". RODRÍGUEZ Y RODRÍGUEZ DE LAMA, I.: Colección Diplomática....ll, doc. 133.

69. "en el Vario que dizen de la Puerta del Castiello,...que hán aledaños la mezquita". Archivo de la Parroquia de San Andrés de Calahorra, signatura n 175.

70. En 1052 la posee el monasterio de Santa María de Nájera; años después, en un documento najerense sin fecha, se afirma la ubicación de esta iglesia "inter castellum Calagurre". RODRÍGUEZ Y RODRÍGUEZ DE LAMA, I.: Colección Diplomática...II, doc. 13. CANTERA MONTENEGRO, M.: Colección documental de Santa María la Real de Nájera, I (siglos X-XII). San Sebastián, 1991, doc. 14. Como ya hemos apuntado, se remontaría al momento hispanogodo en opinión de Bujanda. Ver nota 10. Las alcazabas de Almería, Málaga, Zaragoza, Murcia, Balaguer, Granada, Badajoz, Valencia y Palma de Mallorca cuentan con una mezquita u oratorio privado. MAZZOLI-GUINTARD, Ch.: Ciudades..., pp. 162 y s.

71. CANTERA MONTENEGRO, E.: Las juderías de la Diócesis de Calahorra en la Baja Edad Media. Logroño, 1987, pp. 516 y ss. Así ocurre en Lucena, Toledo, Córdoba, Tudela, Palma de Mallorca, Valencia, Granada, Málaga y quizás Sevilla, Zaragoza y Carmona. MAZZOLI-GUINTARD, Ch.: Ciudades..., pp. 99 y ss.

72. RODRÍGUEZ Y RODRÍGUEZ DE LAMA, I.: Colección Diplomática...II, doc. 42. 


\subsubsection{El Arrabal}

Respecto a la evolución del "suburbium" tardoantiguo, su ubicación extramuros y los continuos asaltos y saqueos provocarían su despoblación; baste con recordar la noticia sobre la destrucción de la iglesia de la sede calagurritana en el año 932 ${ }^{73}$. Tras tomarla Gālib en el 968, la Calahorra musulmana inicia tres cuartos de siglo de estabilidad, hasta la definitiva reconquista cristiana en el 1045. Este periodo favorece su recuperación demográfica, reflejada en la definitiva configuración urbana del arrabal situado junto al río. Además de la estabilidad fronteriza, el desarrollo de la agricultura de regadío sería un importante factor en esta expansión de la ciudad de Calahorra hacia la ribera del Cidacos, una dinámica similar a la observada en localidades de la región levantina ${ }^{74}$. Esta ribera se encuentra desconectada de la ciudad a causa del desnivel topográfico existente; además, este terreno convive con el periódico riesgo de desbordamiento del río. Entonces, ipor qué crece la ciudad hacia esta zona y no hacia la meseta ubicada en la parte elevada? Las razones se encontrarían en la vinculación de esta expansión con la agricultura de regadío, en concreto con los huertos regados por el río Merdero, las mejores posibilidades de comunicación ofrecidas por la calzada y el puente romanos y, quizás también, por el precedente del desaparecido "suburbium" hispanogodo.

El arrabal se articula siguiendo la antigua calzada romana, la actual calle del Arrabal y "via frecuentata" o "calle Regia" de la documentación cristiana del siglo $\mathrm{XI}^{75}$, que conduce al puente romano sobre el $\mathrm{Cidacos}^{76}$. Nada más producirse la reconquista, las donaciones del rey don García nos presentan un arrabal delimitado con algún tipo de cerca, tal y como se deduce del término "clausura"77 y de

73. Siguiendo a M. Risco, identifica la catedral destruida por los árabes con la ubicación de la actual CALATAYUD FERNÁNDEZ, E.: Arquitectura religiosa en la Rioja Baja: Calahorra y su entorno (1500-1650). Los artíficies. Vol. I. Logroño, 1991, p. 251. RISCO, M.: España Sagrada. t. XXXIII, Madrid, 1781, p. 183.

74. A finales del siglo X y principios del XI, también en "Sharq al-Andalus", se constata el abandono de los hábitats en altura, o "ḥuṣūn", y el crecimiento de poblaciones en las vegas de los ríos, donde se amplía la red de regadío y aumenta el número de alquerías. AZUAR RUíZ, R.: "Del hịsn a la madina en el Sharq Al Andalus en época de los reinos de Taifas (siglo XI)". De Toledo a Huesca. Sociedades medievales en transición a finales del siglo XI (1080-1100). Zaragoza, 1998, pp. 29-43.

75. RODRÍGUEZ Y RODRÍGUEZ DE LAMA, I.: Colección Diplomática...II, docs. 44 y 164.

76. Se trata del trazado conjunto de la vía 1 (De Italia in Hispanias) y de la vía 32 (Ab Asturica Tarraconem). Junto a dicho puente se hallado un miliario romano referido a la vía 1 . En la actualidad, de los siete arcos que sumaba el puente de estas calzadas sobre del Cidacos, sólo se conservan restos de uno de sus pilares. PASCUAL MAYORAL, M. P. y GARCÍA RUÍZ, P.: "Las comunicaciones". Así era la vida en una ciudad romana: Calagurris lulia. Calahorra, 2002, pp. 30 y ss.

77. En 1045, unos solares, que el rey pamplonés García Sánchez III dona al monasterio de San Millán de la Cogolla, están situados "in loco iuxta Sancta Maria, de illa carrera qui exit a porta de rivo, dextera partis; et ex illa part qui est clausura urbem ad sursum, usque iungunt se a parte Sancte Marie". UBIETO ARTETA, A.: Cartulario de San Millán..., doc. 235. 
la existencia de puertas; las viviendas dispersas vinculadas a la explotación de los huertos han dado lugar a un espacio que podemos considerar urbano. El principal acceso al arrabal, después de cruzar el puente y siguiendo la calzada romana, es la "porta de rivo" citada en $1045^{78}$, más tarde denominada "de San Miguel". En cuanto a La "Portiella", mencionada en 1098, puede referirse a este mismo ingreso o a un portilllo abierto en el extremo sur de la calle Real ${ }^{79}$. También pudo disponer de otro acceso en el extremo norte de la calle Real, la posteriormente conocida como Puerta de Estella ${ }^{80}$.

Ignoramos el modo en que se articularía este arrabal con el resto de la ciudad. Si tenemos en cuenta que los trazados actuales de la cuestas de la Catedral y el Postigo responden a reformas del siglo XVIII cuyo objetivo era conectar las partes alta y baja de la ciudad ${ }^{81}$, la realidad urbanística de Calahorra nos deja la posibilidad de ascender la Cuesta de las Monjas hacia el arco del Planillo de San Andrés; aún así, se trataría de un arrabal bastante desconectado del resto de la población, un urbanismo disperso similar al de la Tarazona andalusís ${ }^{82}$, circunstancia que se mantiene en los siglos de la modernidad. La desconexión entre ambos espacios urbanos dejaría espacios vacíos, sobre todo aquellos de desnivel más acusado ${ }^{83}$; de ahí que la densidad de ocupación del arrabal no sería elevada, excepción hecha de los márgenes de la calle Real.

La expansión de poblaciones situadas en altura, descendiendo en dirección al río, es un proceso habitual en otras zonas de al-Andalus durante el siglo $X^{84}$. En concreto, lo observamos en ciudades del Levante, Sharq al-Andalus, como

\section{Ibidem.}

79. En 1098, se vende una casa junto a la iglesia de Santa María que linda "ad occidentem vero via frecuentata que pergit ad illa Portiella". RODRÍGUEZ Y RODRÍGUEZ DE LAMA, I.: Colección Diplomática...II, doc. 44. Ésta es la opinión de Fernando Bujanda. LÓPEZ DOMECH, R.: Calahorra..., p. 243.

80. En 1299, el canónigo Juan González compra un huerto "en la puerta d'Estella". RODRíGUEZ Y RODRÍGUEZ DE LAMA, I.: Colección Diplomática...IV, doc. 536. En 1825, al establecer los límites jurisdiccionales de la parroquia de Santa María se dice "bajar por la cuesta de las Monjas hasta la Puerta de Estella y Convento de las Religiosas Carmelitas". BUJANDA, F.: "Demarcación...., p. 545. MATEOS GIL, A. J.: "El urbanismo calagurritano en los siglos del Barroco". Kalakorikos, VI (2001), p. 129.

81. MATEOS GIL, A. J.: Calahorra en los siglos XVII y XVIII. Calahorra, 1996, pp. 9 y s.

82. MAZZOLI-GUINTARD, Ch.: Ciudades..., pp 217 y s.

83. La existencia de estos espacios vacíos es habitual en algunas ciudades andalusíes, siendo empleados en ocasiones como "albacar", espacio intramuros que sirve de refugio al ganado en momento de asedio. Ibidem, pp. 88, 149 y ss. Documentalmente, tan sólo atestiguamos los casales situados "inter casas de domna Tiria et illas quipus fuerant del Çhakib Ibierno iudex" en 1074, así como un huerto "iuxta illum alfondeck" por esas mismas fechas, pues los solares donados a San Millán de la Cogolla en 1045 estarían situados extramuros. RODRÍGUEZ Y RODRÍGUEZ DE LAMA, I.: Colección Diplomática...II, doc. 29. UBIETO ARTETA, A.: Cartulario de San Millán..., doc. 235. CANTERA MONTENEGRO, M.: Colección..., doc. 14.

84. LEVI-PROVENÇAL, E.: "España musulmana hasta la caída del Califato de Córdoba". Historia de España dirigida por Menéndez Pidal, V. Madrid, 1973, pp. 198 y ss. 
Orihuela, Xátiva y Sagunto; en estas localidades, los nuevos barrios se organizan a partir de vías de comunicación preexistentes, incluso, en Sagunto, la calle principal es la antigua calzada romana que recibe el nombre de "Camino Real" ${ }^{85}$. Asimismo, ciudades próximas de origen romano (Tarazona, Huesca y Zaragoza), cuyo hábitat también se redujo su hábitat en la tardo-antigüedad, desarrollan arrabales durante los siglos $\mathrm{X}$ y $\mathrm{XI}^{86}$.

El sector suroccidental de este arrabal está recorrido por un arroyo derivado del Cidacos que en la documentación cristiana recibe el nombre de "rivus Merdarius" o río Merdero (actual Melero) ${ }^{87}$; este curso de agua se adentra en el arrabal, junto a la actual catedral, y discurre paralelo al sur de la calle Real hasta salir por el extremo nororiental de este espacio urbano, junto a la puerta del Río o de San Miguel $^{88}$. El calificativo de "merdarius" nos revela su función de cauce sanitario, o cloaca, del arrabal; aunque tampoco podemos descartar, según apuntamos más adelante, el uso de sus aguas para el desagüe de baños o como fuerza motriz de molinos y otros ingenios. La derivación de cauces que atraviesan el trazado urbano es algo habitual en otras ciudades cercanas como Nájera, cruzada por el río Merdancho que hace las veces de cloaca ${ }^{89}$, o Tudela, donde el arroyo Mediavilla recorre la ciudad, siendo denominado "Merdancho" tras la reconquista cristiana ${ }^{90}$. De igual modo ocurre en poblaciones andalusíes más alejadas como Xátiva, atravesada por la Séquia de la Vila ${ }^{91}$, y Elche, en cuyo trazado urbano se inserta una acequia derivada del río Vinalopó con la finalidad de regar su campos y para usos profilácticos y sanitarios de edificios y espacios públicos, como los baños y el zoco o mercado ${ }^{92}$. En estas dos localidades levantinas, dichos cauces son acequias de riego previas al trazado de las calles ${ }^{93}$; es posible que lo mismo

85. FRANCO SÁNCHEZ, F.: "Estudio comparativo del urbanismo islámico de seis poblaciones de la Vía Augusta". Simposio internacional sobre la ciudad islámica. Ponencias y comunicaciones. Zaragoza, 1991, pp. 355-362.

86. CORRAL LAFUENTE, J. L.: "Las ciudades de la Marca Superior de Al-Andalus". Simposio internacional sobre la ciudad islámica. Ponencias y comunicaciones. Zaragoza, 1991, pp. 260 y s. MAZZOLI-GUINTARD, Ch.: Ciudades..., pp. 259 y s.

87. En 1145, Sancho III de Castilla dona a la catedral de Calahorra un solar situado en la alhóndiga que cuenta con los siguientes linderos: "A septentrione, domun Garcie de Anderi et Callis Regia sum furno; A meridie, rivus Merdarius. Ab occidente balneis". RODRÍGUEZ Y RODRÍGUEZ DE LAMA, I.: Colección Diplomática...II, doc. 139.

88. El mapa de Tomás López, publicado por Coello en 1851, permite seguir su recorrido. MATEOS GIL, A. J.: Calahorra..., p. 71.

89. También Ilamado Mérdanix, Merdaniel o Sórdido. GARCÍA TURZA, F. J.: "Morfología de la ciudad de Nájera en la Edad Media". III Semana de Estudios Medievales de Nájera. Logroño, 1993, p. 64.

90. HERNÁNDEZ CHARRO, M. C.: "Agua y poblamiento. Notas sobre la configuración del territorio de la Tudela andalusí". Studia Historica. Historia Medieval, XXIV (2006), p. 330.

91. FRANCO SÁNCHEZ, F.: “Estudio comparativo del urbanismo..., p. 358.

92. AZUAR RUÍZ, R.: "Del hișn a la madīna..., p. 36.

93. Ibidem. FRANCO SÁNCHEZ, F.: “Estudio comparativo del urbanismo..., p. 358. 
le ocurriese al río Merdero pues, según ya hemos apuntado, el desarrollo de la agricultura de regadío sería uno de los factores que determinan el crecimiento del arrabal. Además, tal y como veremos al analizar el sistema hidráulico calagurritano, este cauce sería una de las acequias calagurritanas más antiguas.

En el extremo suroccidental del arrabal, se situaba la catedral hispanogoda, de dimensiones mucho más reducidas que el actual ${ }^{94}$. Tras su destrucción en el 932, esta iglesia pudo ser sustituida por una mezquita de similares dimensiones, pues esta transformación resulta habitual en otras ciudades de la Marca Superior de al-Andalus (Tarazona, Zaragoza y Huesca) ${ }^{95}$. Además, hay que tener en cuenta la cercanía de los baños, situados entre la calle Real y el río Merdero ${ }^{96}$; pues, según analizamos en el siguiente párrafo, estos espacios destinados a purificaciones rituales se hayan vinculados a los centros de oración. Por tanto, sin que ello sea óbice para la existencia de un pequeño oratorio en la zona elevada de la urbe, resulta plausible la ubicación de la mezquita en el arrabal, ocupando el espacio de la antigua iglesia hispanogoda y parte del de la actual catedral ${ }^{97}$.

Según hemos adelantado, se documentan unos "balneis" en 1145, situados entre la calle Real y el río Merdero. Aunque no podemos afirmarlo, conjeturar su origen islámico nos parece razonable. Primeramente, no podemos relacionarlos con ninguna de las termas romanas conocidas, pues cuentan con otras localizaciones ${ }^{98}$. En segundo lugar, tras la reconquista cristiana, resulta habitual

94. Siguiendo a Llorente, Calatayud Fernández la hace corresponder con la nave norte de la actual, abarcando sólo 16 varas de largo y seis de ancho CALATAYUD FERNÁNDEZ, E.: Arquitectura religiosa..., p. 251. LLORENTE, J. A.: Apuntes históricos..., p. 29. La correspondencia con la nave norte de la actual catedral no sería exacta, pues las fases constructivas posteriores al templo original han ido ganando en proximidad al cerro para eludir las crecidas del Cidacos; de ahí que el actual muro norte sepulte parte de la necrópolis medieval, cuyas tumbas también se orientan con cierta deriva respecto al muro de la catedral actual. TUDANCA CASERO, J. M. y LÓPEZ DE CALLE CÁMARA, C.: “Entorno urbanístico..., p. 185.

95. CORRAL LAFUENTE, J. L.: "Las ciudades de la Marca Superior..., p. 261.

96. "A septentrione,... Gallis Regia cum furno. A meridie, rivus Merdarius. Ab occidente, balneis". RODRÍGUEZ Y RODRÍGUEZ DE LAMA, I.: Colección Diplomática...II, doc. 139.

97. Aunque en Badajoz y Palma de Mallorca la mezquita aljama se encuentra dentro de la alcazaba, en la mayoría de las ciudades andalusíes ambos elementos ocupan espacios distintos. MAZZOLI-GUINTARD, Ch.: Ciudades..., pp. 140 y ss.

98. Se han descubierto termas romanas en la calle San Andrés, en el solar de la antigua Fábrica Torres (conocido popularmente como "La Clínica") y en las calles La Enrramada, Pedro Gutiérrez, Miguel de Cervantes y Doctor Chavarría. ANDRÉS HURTADO, G.: "Seguimientos arqueológicos en varios puntos del casco antiguo de la ciudad de Calahorra". Estrato. Revista Riojana de Arqueología, IX (1998), pp. 35-44. LUEZAS PASCUAL: "Arqueología urbana en Calahorra". Estrato. Revista Riojana de Arqueología, IX (1998), pp. 24-30. LUEZAS PASCUAL, R. A. y ANDRÉS HURTADO, G.: "Obras hidráulicas en el municipium Calagurris Iulia". Estrato. Revista Riojana de Arqueología, X (1999), pp. 29-31. ANTOÑANZAS SUBERO, M. A. y TEJADO SEBASTIÁN, J. M.: "En las termas". Así era la vida en una ciudad romana: Calagurris lulia. Calahorra, 2002, pp. 141 y ss. 
que los espacios públicos musulmanes pasen al realengo; así, el monarca figura como propietario de estos baños y de la "domum cum forno" que linda con ellos en $1098^{99}$. También es frecuente esta asociación de baños y horno, pues después de la reconquista cristiana se solía utilizar como horno de cocción o fragua la misma caldera usada para calentar el agua ${ }^{100}$. La finalidad de estos baños o "hammām", a medio camino entre lo religioso, lo sanitario y lo lúdico, determina su ubicación en el arrabal calagurritano. Esta localización se explica en función de su proximidad al cauce del Cidacos que facilita la aducción del agua y su desagüe, seguramente al río Merdero, de la ya comentada vecindad con la mezquita, pues en ellos se realiza la purificación mayor o "gusl" de cara a la oración, así como de su cercanía al zoco y a dos accesos a la ciudad (Portilla y Puerta de San Miguel), pues viajeros y mercaderes serían posibles clientes e incluso se aprovecharía el calor generado para albergarlos allín ${ }^{101}$.

El arrabal calagurritano, sobre todo la calle Real, acogería intercambios comerciales, así como el almacenamiento y la transformación de la producción agraria; todas ellas actividades económicas propias de una zona de contacto del núcleo urbano con su entorno periurbano ${ }^{102}$. La cocción del pan pudo llevarse a cabo en la "domum cum forno" que en 1098 se localiza en la susodicha calle Real, junto a la catedral de Santa María ${ }^{103}$; sin embargo, resulta dudoso su origen islámico porque en las ciudades andalusíes suele estar prohibido instalar hornos en la calle por el peligro de incendio y las molestias que el humo puede ocasionar ${ }^{104}$. Además, como antes hemos mencionado, puede tratarse de un aprovechamiento, ya en época cristiana, de la caldera de los baños vecinos.

Los productos agrarios del entorno urbano, en bruto (cereal, hortalizas, olivas,...) o ya transformados (cereal, harina, aceite,...), y otras mercancías de pri-

99. En 1161, Elías Maingo vende los baños y el horno, que seguramente ha recibido del monarca, a la catedral de Calahorra. RODRÍGUEZ Y RODRÍGUEZ DE LAMA, I.: Colección Diplomática...II, docs. 44, 139 y 208.

100. EPALZA, M. de: "Espacios y funciones..., p. 18.

101. Ibidem. MAILLO SALGADO, F.: Vocabulario básico de historia del Islam. Madrid, 1987, pp. 68 y s. Coincidencia de la ubicación de los baños con las mezquitas en Toledo. DELGADO, C.: "Estructura urbana de Toledo en época islámica". Simposio internacional sobre la ciudad islámica. Ponencias y comunicaciones. Zaragoza, 1991, p. 330. Proximidad de los baños a las mezquitas en Málaga siempre que lo permite el abastecimiento de agua. AGUILAR, M. D.: "Mezquitas y baños de Málaga musulmana". Simposio internacional sobre la ciudad islámica. Ponencias y comunicaciones. Zaragoza, 1991, p. 398.

102. EPALZA, M. de: "Espacios y funciones..., pp. 19 y s.

103. En 1098, junto a una casa de la calle Real, se cita "dextere partis domum cum forno quod est regis". RODRÍGUEZY RODRÍGUEZ DE LAMA, I.: Colección Diplomática....II, doc. 44.

104. MAZZOLI-GUINTARD, Ch.: Ciudades..., p. 120. Aunque casi un siglo después del periodo de nuestro estudio, Alfonso I "el Batallador" facilita a los clérigos calagurritanos la destrucción de un horno, ubicado junto al altar de la catedral, cuyo humo les molesta. RODRíGUEZ Y RODRÍGUEZ DE LAMA, I.: Colección Diplomática...III, doc. 391. 
mera necesidad (aceite, carbón, carne, madera,...), son artículos destinados al zoco o mercado y se almacenarían en la "alfondeck", "alfondega", "al-funduq" o alhóndiga situada en dicha calle, cerca de los citados baños y horno. La progenie islámica de este edificio podemos aventurarla por su temprana mención en la segunda mitad del siglo XI, el hecho de su titularidad regia y al encontrarse ya en desuso apenas un siglo después de la reconquista; en 1145, Sancho III de Castilla dona a la catedral de Calahorra "meum solarem quod est in illa Alfondega"105. Esta alhóndiga también serviría de alojamiento a comerciantes foráneos (muchas veces custodiando sus mercancías), de ahí su ubicación cerca de dos entradas a la ciudad, la Puerta de San Miguel y la Portilla ${ }^{106}$. El zoco o mercado dispondría de un modesto radio de acción, centrado en el abastecimiento de la ciudad a partir de los campos circundantes ${ }^{107}$. Por tanto, tendría un carácter periódico y estaría localizado extramuros o, dentro del arrabal, cerca de la mezquita y de la alhóndiga; en ambos casos se buscaría la proximidad de los accesos a la ciudad y de los principales ejes de comunicación, la calle Real y el puente sobre el Cida$\cos ^{108}$. Intramuros, los tenderetes desmontables quizás dieran lugar a infraestructuras definitivas como la tienda que, situada en la parte baja de una casa de dicha calle, es mencionada en $1165^{109}$. En algunas ciudades islámicas la presencia del zoco en el arrabal puede responder también a la necesidad de un mayor espacio

105. Después del año 1052, se localiza una pieza "prope illas areas de illo Alfondeck" y unos huertos "iuxta illum alfondeck". CANTERA MONTENEGRO, M.: Colección..., doc. 14. En 1145 Sancho III dona a la catedral un solar "in illa alfondega", que limita al norte con la calle Real y al sur con el río Merdero. RODRÍGUEZ Y RODRíGUEZ DE LAMA, I.: Colección Diplomática...II, doc. 139. Sénac considera probable el origen islámico de esta alhóndiga. SÉNAC, Ph.: "El dominio musulmán..., p. 26.

106. DELGADO, C.: "Estructura urbana de Toledo..., p. 329. MAILLO SALGADO, F.: Vocabulario..., p. 23. "Al funduq" es también el lugar donde se encuentran agrupados topográficamente los comerciantes. CHALMETA, P.: "Organización artesano-comercial de la ciudad islámica". Simposio internacional sobre la ciudad islámica. Ponencias y comunicaciones. Zaragoza, 1991, pp. 97, 99, 102 y s. El lugar de almacenamiento del cereal serían "alhorines" y "alforins", "almodins" y "almodíes". EPALZA, M.: "Espacios y funciones..., p. 19. En Calahorra, existe actualmente una Calle del Alforín, ubicada en la parte alta de la ciudad, en el barrio de San Andrés; quizás se deba a una realidad posterior de época cristiana, concretamente al alforín común de la catedral de Santa María con las parroquias de San Andrés y San Cristóbal. RODRÍGUEZ Y RODRÍGUEZ DE LAMA, I.: Colección Diplomática...III, doc. 401.

107. A pesar de contar con una alhóndiga y un puente sobre un río secundario, el Cidacos, carecemos de información directa sobre su zoco o mercado, de ahí que asimilemos la Calahorra islámica al "tipo 4" establecido por Mazzoli-Guintard a la hora de clasificar las ciudades andalusíes en función de sus transacciones mercantiles. MAZZOLI-GUINTARD, Ch.: Ciudades..., p. 120.

108. Estos criterios se siguen también en la ubicación de los zocos de otras ciudades andalusíes como Toledo y Sagunto. EPALZA, M. de: "Espacios y funciones..., pp. 19 y s. DELGADO, C.: "Estructura urbana de Toledo..., p. 329. CORRAL LAFUENTE, J. L.: "Las ciudades de la Marca Superior..., p. 277. En la actualidad se conserva la calle Zoquero, bocacalle de la calle del Arrabal.

109. RODRÍGUEZ Y RODRÍGUEZ DE LAMA, I.: Colección Diplomática...II, doc. 219. 
que el disponible en la parte elevada ${ }^{10}$; sin embargo, en el caso calagurritano consideramos más relevante la necesidad de una mejor comunicación con un entorno periurbano que aporta gran parte de los productos intercambiados, sobre todo los frutos perecederos de los huertos cercanos.

\subsubsection{Caracterización urbana de la Calahorra islámica}

Según lo expuesto hasta ahora, no podemos considerar a Calahorra como una "madīna" o ciudad islámica propiamente dicha. Ya hemos observado que la mayoría de las crónicas musulmanas coetáneas se refieren a ella como un "ḥișn" dentro del término de Tudela. Los únicos autores árabes que conceden a Calahorra la categoría de "madinna" se hallan ajenos a la realidad de dicho momento histórico, tanto por las fuentes empleadas como por la distancia cronológica. Así, Al-Bakrī (1014-1094), un autor contemporáneo, sigue la llamada "división eclesiástica de Constantino" dentro de la geografía diocesana visigoda, situando a Calahorra en la zona tercera o Celtiberia ("Saltabariya"), cuya capital es Tarragona, y considerándola ciudad en virtud de su carácter de sede episcopal ${ }^{111}$. Algo similar ocurre con autores muy posteriores a la reconquista cristiana; es el caso de Yāqūt (1175-1225), quien Ilama "madinna" a todas las poblaciones dependientes de Tudela, sea cual sea su tamaño; así como el de Al-Idrīsĩ (1100-1154), cuya obra sitúa la ciudad de Calahorra a la vez en el país cristiano del Templo y en el sobredimensionado clima de Arnedo ${ }^{12}$.

Además, los datos disponibles no permiten, ni mucho menos, caracterizarla con los elementos propios de una "madinna", ya sea en función de los criterios de Pedro Chalmeta o según los expresados por Mikel de Epalza ${ }^{113}$. Calahorra no es una sede administrativa ni judicial, su volumen demográfico es muy limitado y desconocemos las características se su mezquita y la periodicidad de su mercado. Por consiguiente, al estudiar las ciudades de la Marca Superior de alAndalus, Corral Lafuente y Souto Lasala no la consideran ya que, a su limitada relevancia en época visigoda, se suma la postergación respecto a la recién fundada Tudela, en cuya órbita queda incluida, y la marginación frente al papel

110. CHALMETA, P.: “Organización artesano-comercial..., p. 93.

111. BELTRÁN VIDAL, E.: Geografía de España de Abu Ubayd Al-Bakri. Zaragoza, 1982, pp. 16 y s. VALLVÉ BERMEJO, J.: La división territorial de la España musulmana. Madrid, 1986, pp. 210 y s., 217 y s.

112. ABD AL-KARIM, G.: "La España musulmana en la obra de Yaqut (s. XII-XIII)". Cuadernos de Historia del Islam, VI (1974), p. 257. Incluso, Al-Idrīsī localiza el nacimiento de uno de los brazos del río Ebro en las inmediaciones de Calahorra. BLÁZQUEZ, A.: Geografía de España de Idrisí. Valencia, 1974, pp. 105 y s., 138, 151 y 180.

113. CHALMETA, P.: "Organización artesano-comercial..., p. 94. EPALZA, M. de: "Un modelo operativo..., pp. 137-149. 
centralizador de Zaragoza ${ }^{114}$. A estas razones, hay que añadir el carácter excesivamente expuesto de Calahorra respecto de los ataques cristianos; las continuas conquistas y saqueos reducirían la población a un mero asentamiento militar, el "hiṣn Qalahurra".

Ya muy tarde, en el 968, se inicia un periodo de estabilidad que permite el desarrollo de la vida urbana en el arrabal, pero sin cristalizar en una auténtica "madinna", debido en gran parte a su temprana reconquista en el 1045. Este arrabal calagurritano se asimila al modelo operativo de hábitats rurales de menor entidad, enunciado por Epalza y aplicado por Franco Sánchez a varias poblaciones de Sharq Al-Andalus (Ontinyent, Bocairent y Beneixama) ${ }^{115}$. Este esquema se haya definido por un eje central (calle Real) en uno de cuyos extremos, cerca de sus accesos (Portilla y Puerta de San Miguel), se localizan la mezquita, los baños y otros servicios como la alhóndiga, el zoco, el horno, la era, el molino,..., buscando atender también las necesidades de los campesinos instalados extramuros.

En definitiva, la Calahorra islámica, en su inconexo conjunto de "ḥișn" y arrabal, se trataría de una pequeña ciudad propia de los "țugūr"; apenas supera los límites del mundo rural, depende administrativamente de una "madinna", Tudela, y se desarrolla alrededor de una posición defensiva, concebida para controlar un territorio circundante de modestas dimensiones ${ }^{116}$.

\subsection{Los espacios periurbanos}

Dos son los factores que configuran el entorno humanizado alrededor de Calahorra: la presencia de la propia ciudad, donde se consume y comercializa la producción agraria, y las infraestructuras de canalización del agua del Cidacos que, desarrollando una agricultura de regadío, expanden la urbe hacia dicho río con la creación del arrabal. Sirva de ejemplo la imagen de las parcelas de cultivo documentadas entre 1045 y 1076, cuyas referencias espaciales son en su mayoría los caminos que parten de ella a distintos lugares del término y a localidades vecinas ("via de Acuto", "via de Villa Nova", "via de Almonezer" y "via que ducit Abtonium"), las infraestructuras de regadío y la propia ciudad de Calahorra; sumando todos ellos dieciocho de las treinta referencias registradas en total.

Una vez ya analizado el espacio urbano, llega el momento de estudiar el otro elemento definitorio del espacio periurbano: la red de captaciones y conducciones hidráulicas creadas en torno a la Calahorra islámica. A continuación, analizamos las actividades de producción y transformación agraria, así como residenciales, que alberga el espacio definido por este sistema hidráulico.

114. CORRAL LAFUENTE, J. L.: "Las ciudades de la Marca Superior..., pp. 253-59. SOUTO LASALA, J.: "El noroeste..., p. 260.

115. FRANCO SÁNCHEZ, F.: "Estudio comparativo del urbanismo..., pp. 362 y ss.

116. MAZZOLI-GUINTARD, Ch.: Ciudades..., pp. 376 y s. 


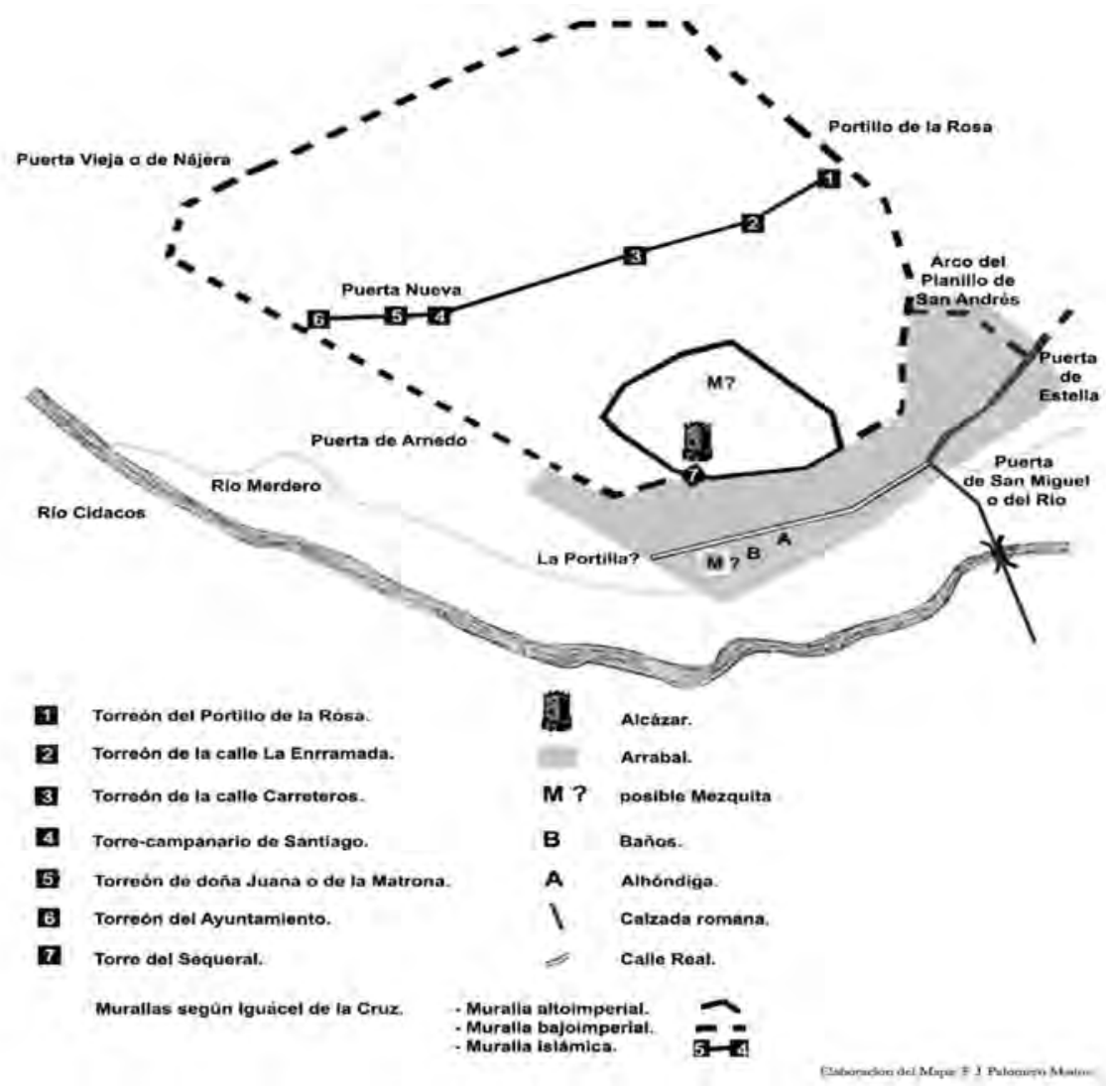

Organización del espacio urbano en la Calahorra islámica.

\subsubsection{Trazado del sistema hidráulico}

Disponemos de información acerca del abastecimiento de agua a Calagurris durante la época imperial a través del acueducto de Sierra La Hez ${ }^{117}$. Pasando de una hidráulica consuntiva a otra productiva, podemos hablar de la presa

117. A pesar de la hipótesis de Mezquíriz, los estudios de altimetría descartan al acueducto de Lodosa-Alcanadre como uno de los medios del abastecimiento de agua a la Calahorra romana; quizás sus destinatarios fuesen núcleos de población situados junto a la orilla del Ebro como Sarta o Resa. MEZQUÍRIZ IRUJO, M. A.: "El acueducto de Alcanadre-Lodosa". Trabajos de Arqueología Navarra, I (1979), pp. 134-148. PASCUAL MAYORAL, M. P.: "Abastecimiento de agua a Calagurris". Miscelanea. Arqueología de Calahorra. Calahorra, 1991, pp. 55-104. PASCUAL MAYORAL, M. P. y GARCÍA RUÍZ, P.: "El abastecimiento de agua". Así era la vida en una ciudad romana: Calagurris lulia. Calahorra, 2002, pp. 51-59. 
romana de la Degollada que recoge las aguas de los irregulares cursos de la yasa o torrente del mismo nombre y, posiblemente, desde alguna desviación de la orilla derecha del Cidacos. Su contenido se destinaba al riego de los campos de la margen derecha de dicho río, documentándose en su área de influencia los asentamientos de Campo Bajo, Los Torrobales, Perdiguero, La Ambilla,... y, sobre todo, la Torrecilla, de mayores dimensiones y situado junto al propio embalse $^{118}$. No podemos afirmar el aprovechamiento de las infraestructuras hidráulicas romanas durante el periodo islámico, sino tan sólo su presencia. En 1046, se habla de un "aqueductum" en el término de Sorbán, seguramente restos del acueducto de Sierra La Hez. Sin embargo, no creemos que, en el improbable caso de estar operativo, este acueducto fuese empleado por los musulmanes para el riego de la huerta calagurritana; más bien, siguiendo el ejemplo de otras ciudades andalusíes, se dedicaría a las necesidades hídricas urbanas ${ }^{119}$. Lo mismo ocurriría con la presa de la Degollada, cuya localización la desvincula de la red hidráulica islámica.

Puestos a reconstruir el entramado de conducciones hídricas, en el momento de la conquista cristiana se mencionan dos acequias, "rivo Molinare" y "rivo Caballero" en 1045. Asimismo, podemos aventurar el origen islámico del "rio de Vencabla" y el "rivus Merdarius", pues, aunque ambos se documentan más tarde, la etimología del primero es claramente árabe, mientras la existencia del segundo es un imperativo de la propia estructura del arrabal calagurritano. Además, resulta clara la etimología árabe de las palabras "jerigonzas", "ajeriganzas", "geriganzas", "axarigazas" o "axaregaçias", términos aplicados a las primeras comunidades de regantes de los valles del Cidacos y el Alhama ${ }^{120}$. Del vocablo árabe "aš-šarīk" deriva "exarico", aparcero, y "axarigaza" o "axaricança", aparcería ${ }^{121}$; es decir, la palabra "jeriganza" haría referencia a la participación de los distintos regantes en la infraestructura hidráulica y en el aprovechamiento del agua que por ella se conduce, tal y como refleja el verbo "jaricar" o "juntar hilas de agua"122. Incluso, según López Arroyo, la costumbre

118. PASCUAL MAYORAL, M. P. y GARCÍA RUÍZ, P.: "El abastecimiento..., pp. 55 y ss. VALORIA ESCALONA, M. A.: "Calahorra arqueológica". Miscelánea de arqueología riojana. Logroño, 1973, pp. 143 y ss. VV. AA.: Miscelánea. Arqueología de Calahorra. Calahorra, 1991, p. 279.

119. RODRÍGUEZ Y RODRÍGUEZ DE LAMA, I.: Colección Diplomática...II, doc. 7. FRANCO SÁNCHEZ, F.: "Estudio comparativo del urbanismo..., pp. 356 y s. MAZZOLI-GUINTARD, Ch.: Ciudades..., p. 189.

120. REYES MANZANO, A.: Mandar es Juzgar: La Institución de la Alcaldía de Campo en Calahorra. Calahorra, 2007, p. 24.

121. "compadre, quiñero que tiene ally parte, compañero, parcionero, xariq - axaráq". CORRIENTE, F.: El léxico árabe andalusí según P. de Alcalá. Madrid, 1988, p. 108.

122. "el mur. jaricar, juntar hilas de agua, con el sustantivo verbal jarique". CORRIENTE, F.: Diccionario..., p. 86. Su primera mención documental en Calahorra nos remite al año 1317, cuando se efectúa un apeamiento de las heredades regadas por el río Merdero para repartir los 
del Tribunal de las Aguas de Calahorra de juzgar los delitos en la puerta de la catedral proviene de los primeros años tras la reconquista, pues los agricultores musulmanes, protagonistas del sistema hidráulico, tienen prohibida su entrada al templo cristiano ${ }^{123}$.

A causa de la "naturaleza ultraestable" de los sistemas hidráulicos ${ }^{124}$, identificamos estos cauces con las actuales acequias de regadío. La documentación sitúa al "rivo Caballero" por encima del término de Sorbán"125, siendo hoy en día una derivación de la Madre de Sorbán que, a partir del camino de Murillo ${ }^{126}$, discurre hasta el término del Valladar, donde la Madre del Sordillo devuelve sus aguas al Cidacos. Por tanto, al documentar este cauce secundario, presuponemos la existencia de la acequia principal, es decir, la Madre de Sorbán. Ésta toma aguas en la margen izquierda del Cidacos unos cinco kilómetros río arriba de Calahorra en el paraje de Los Royales y desciende paralela al río para acabar rodeando la ciudad por el norte, donde se divide en la acequia de Valvedado, que a través de la Madre del Palo desemboca en la Madre de Melero, y, más adelante, en el citado río Caballero ${ }^{127}$. Respecto al "rivo Molinare", resulta sencillo identificarlo con la actual Madre de los Molinos, no sólo por el nombre sino también por su trazado a lo largo de la margen derecha del Cidacos, cruzando el camino de los Agudos frente a la propia ciudad de Calahorra ${ }^{128}$. En la

gastos del mantenimiento de dicha acequia; este recuento se realiza entre el cabildo catedralicio, el concejo de la ciudad y "todos los axarigues de la axarigaza del río Merdero de la cibdad de Calahorra". SAÍNZ RIPA, E. y HERNÁEZ IRUZUBIETA, V.: Documentación Calagurritana del Siglo XIV. Archivo Catedral. Vol. I. Logroño, 1995, doc. 72.

123. LÓPEZ ARROYO, J. M.: Aspectos jurídicos del regadío tradicional riojano. Logroño, 1994 , p. 83.

124. BARCELÓ, M.: "El diseño de espacios irrigados en Al-Andalus: Un enunciado de principios generales". El agua que no duerme. Granada, 1996, pp. 58-60. "Las unidades hidráulicas actuales, a pesar de sus sucesivas reconstrucciones, reproducen en muchos casos su aspecto original". KIRCHNER, E. y NAVARRO, C.: "Objetivos, métodos y práctica de la arqueología hidráulica". El agua que no duerme. Granada, 1996, p. 105.

125. "in Sorban, sub rivo Caballero". UBIETO ARTETA, A.: Cartulario de San Millán..., doc. 235.

126. En las Ordenanzas de 1517, se establece "que el valladar debaxo de la carrera Murillo sea abierto, e puesto en debido estado por las heredades que ba hasta dar en el río Caballero". REYES MANZANO, A.: Mandar es Juzgar..., p. 179. El propio nombre de esta acequia, el topónimo "Sorbán", puede ser de origen árabe; en concreto, derivaría de "xorbá". "Sorbá: Es en España pueblo del obispado de Vicen en Catalunia. Es xorbá, que, en arábigo, significa bebida..." GUADIX, D. de: Recopilación de algunos nombres arábigos que los árabes pusieron a algunas ciudades y a otras muchas cosas. Gijón, 2005, p. 947.

127. La "Regulación de las coseras del Sorbán" nos permite seguir el trazado de esta acequia, desde la presa del río Mayor o Cidacos a la Algarrada, pasando por el Puente del Cabezo y los caminos de Logroño, Murillo y San Adrián. REYES MANZANO, A.: Mandar es Juzgar..., p. 227.

128. En 1045 se sitúa una heredad "iuxta rivo molinare, et de alia parte, via que dicunt de Acutu partis aquam ab aspectu urbem sitam". UBIETO ARTETA, A.: Cartulario de San Millán..., doc. 235. 
actualidad, la Madre de los Molinos tiene su captación en la presa de Livillos (unos metros aguas arriba de donde venía haciéndolo en siglos anteriores), discurre paralela a la orilla diestra del Cidacos y, a la altura de urbe, gira en dirección hacia levante hasta llegar a Ribarroyas, paraje donde se divide en las acequias de la Portalada, río de los Caños y Ontañón ${ }^{129}$.

Las Madres de Sorbán y de los Molinos constituyen las acequias principales al canalizar las aguas en las dos márgenes del Cidacos; de ahí que resulte lógica su presencia en el sistema hidráulico de época islámica. Esta jerarquía se deduce al observar su representación cartográfica ${ }^{130}$. Ambos cauces discurren por una topografía más elevada, configurando la "línea de rigidez" del sistema hidráulico calagurritano y límite superior de la zona regable ${ }^{131}$; además, según ya hemos apuntado, son el origen de gran cantidad de cauces secundarios. En razón de su importancia troncal en dicho entramado hidráulico, las Ordenanzas de Campo de la Ciudad de Calahorra, otorgadas por la reina Juana y su hijo Carlos I en 1517, atribuyen la titularidad y la gestión de ambos ríos y de sus puentes al concejo de Calahorra, frente al carácter privado que predomina en las restantes acequias ${ }^{132}$. En consecuencia, las penas impuestas a quienes paren arquillas de tierra en los primeros tramos de dichas acequias y para los culpables de cortar y desviar su caudal, cien y doscientos maravedíes respectivamente, suponen el techo de las sanciones contenidas en dicho reglamento ${ }^{133}$. Además de su condición de cauces matrices en este sistema hidráulico, la preeminencia de estas dos acequias es también consecuencia de su antigüedad, criterio que les concede preferencia a la hora de aprovechar el agua captada del Cidacos, tal y como reflejan las citadas ordenanzas al diferenciar entre regadíos viejos y nuevos ${ }^{134}$.

129. A lo largo de su recorrido, cuenta con presas que derivan otros tantos cauces secundarios: la Ambilla y San Lázaro, citados en las Ordenanzas de Campo de la Ciudad de Calahorra otorgadas por la reina Juana y su hijo Carlos I en 1517, y los del Chorrón, Brazal de vecinos, del Caño, Capazo, Zapatero, Sies,..., mencionados en la sentencia del pleito entre Calahorra, Aldeanueva de Ebro y Rincón de Soto sobre el aprovechamiento de las aguas de la margen derecha del Cidacos en 1707. REYES MANZANO, A.: Mandar es Juzgar..., pp. 173, 175 y $224 .$.

130. En un mapa del proyecto de acequia a partir del río Ebro elaborado en 1752, se puede seguir el recorrido de estos dos cursos de agua. CRISTÓBAL FERNÁNDEZ, E. y MARTíN ESCORZA, C.: "Un proyecto de acequia de riego para Calahorra en el siglo XVIII". Kalakorikos, VII (2002), p. 228.

131. BARCELÓ, M.: "El diseño de los espacios irrigados..., 1996, p. 51.

132. Salvo los puentes del molino de los abades, el de las piezas de Sansol y los del camino de la Torrecilla. Incluso, la jeriganza de Sorbán es una de las pocas que cuenta con más de un mayordomo durante la edad Moderna. REYES MANZANO, A.: Mandar es Juzgar..., pp. 25, 173 y 181.

133. Ibidem, pp. 173 y 175.

134. "que en las axariganzas de los regadíos nuevos y viexos de esta ciudad y su tierra, ayan de ser sacadas las aguas, y a limpiados los ríos,... que las axariganzas más antiguas, prefieran en el regar a las otras más nuebas, cada más según al tiempo que se sacó... que los dichos alcaldes ayan de proveer, e entender en todas las alfariganzas nuevas, e viexas, e disponer de ellas". 
Por debajo de la línea de rigidez establecida por ríos Molinar y de Sorbán, se encuentra el "rio de Vencabla", o actual acequia de Mencabla; se documenta en fechas más tardías, años 1259 y $1260^{135}$. Su captación, en la orilla izquierda del Cidacos ${ }^{136}$, se halla aguas abajo de la Yasa del Arco; a partir de entonces, recorre el límite sudoeste de la ciudad, pasando junto a la puerta de Arnedo, hasta desembocar en el "rivus Merdarius", actual Madre de Melero. Ya hemos hablado de este río Merdero, desviado del Cidacos, que, tras cruzar el Arrabal, abandona la ciudad a la altura de la puerta de San Miguel y continúa por la "Torre del Canto de la Villa de la Puerta de Estella", "Rallos de la Puente", "rencon de la caleiuela", "río las Presiellas", "cal de Magoyo", la Almunia y "carrera de Merdero" hasta la Algarrada, según el trazado detallado en un apeamiento de $1317^{137}$. Desde la Algarrada, donde se encuentra próximo al cauce del Sorbán ${ }^{138}$, devolvería sus aguas al Cidacos ${ }^{139}$. Si nos atenemos al modelo de crecimiento de un sistema hidráulico, cuyas ampliaciones se llevan a cabo elevando dicha "línea de rígidez" con nuevas captaciones situadas río arriba, estas acequias de Mencabla y Merdero serían las más antiguas.

\subsubsection{Actividades económicas en el espacio periurbano}

Por debajo de la "línea de rigidez" de este sistema hidráulico se configura un amplio espacio en torno a Calahorra apto para un cultivo intensivo irrigado. Además, la cercanía a la ciudad permite una más estricta vigilancia y cuidado de los preciados frutos de árboles y huertas. La dedicación hortícola de ambas riberas del Cidacos resulta evidente, aunque la documentación cristiana no lo explicite hasta el siglo XII ${ }^{140}$; salvo las menciones a los "ortis iuxta illum alfondeck" y a los

"...por quanto de antigüedad tiene Lambilla, donde el camino de la Barquilla arriba, donde el sábado a la hora de nona hasta el lunes salidos de tercia, el agua del río Molinar,... que al río San Lázaro la sea guardada su preminencia de la parte de agua que de antigüedad tiene". Ibidem, pp. 173, 175, 177 y 185.

135. "las casas d'yuso del hospital d'Santi Spiritus, qui habet allactaneos... de la otra parte, el rio de Vencaubla". "my uerto en rio de Vencabla". RODRÍGUEZ Y RODRíGUEZ DE LAMA, I.: Colección Diplomática...IV, docs. 243 y 250.

136. Se halla dibujada en una acuarela fechada hacia 1720. Archivo Municipal de Calahorra, sección Alcaldía del campo, serie Expedientes judiciales, signatura 216/6. REYES MANZANO, A.: Mandar es Juzgar..., pp. 120 y s.

137. SAÍNZ RIPA, E. y HERNÁEZ IRUZUBIETA, V.: Documentación Calagurritana..., doc. 72.

138. En 1475, el concejo de Calahorra concede al canónigo don Juan López de Entrena que, ante la escasez de agua del río Merdero, pueda regar un cerrado en la Algarrada a partir de la "axaregaçia" del río de Sorbán. SAÍNZ RIPA, E. y ORTEGA LÓPEZ, A.: Documentación Calagurritana del siglo XV. Archivo catedral. Logroño, 2004, doc. 104.

139. Actualmente, desemboca en la Madre de Pesenzano que lleva sus aguas de nuevo al Cidacos, poco antes de su confluencia en el Ebro.

140. Nos referimos a los huertos los situados en San Felices, hacia 1120, en Sansol, en 1126, y en Rípodas, tres años más tarde. RODRÍGUEZ Y RODRÍGUEZ DE LAMA, I.: Colección Diplomática....II, doc. 87 y 97. 
"ortos de illa porta de Arneto", contenidas en un documento sin fecha de la segunda mitad del siglo XI, o que traduzcamos como ciruelo el "spino" situado cerca de la ciudad, junto al río Molinar, en $1045^{141}$. Entre estos huertos se alternan viñas, generalmente emparradas, pues se limitan a producir uvas para su consumo sin fermentar, bien sean frescas o pasas, a causa de la prohibición religiosa de ingerir bebidas alcohólicas. Así, documentamos un parral en las inmediaciones de Calahorra, "iuxta porta rivo, dextera parte sito", donado por el rey pamplonés al monasterio de San Millán de la Cogolla el 31 de mayo de 1045, sólo un mes después de la reconquista cristiana ${ }^{142}$. En ocasiones, estas parras enredan sus sarmientos en las ramas de los árboles frutales, dando lugar al denominado "cultivo promiscuo"143. En 1046, tenemos un ejemplo de este tipo de cultivo en la "vinea...qui dicitur Pirorum", es decir, que se sitúa en una parcela de perales, seguramente emparrada en ellos; menciones posteriores nos permiten localizarla cerca de la Portilla del arrabal ${ }^{144}$. También podemos considerar como "cultivo promiscuo" el "ortus vitibus", situado en el término de Rípodas, al sur de la ciudad, que linda con otro "ortus vitium Petri Geice" en $1129^{145}$.

En esta zona regable, también abundan las parcelas de cereal; nos referimos a las dos tierras en Perenzano, los agros en Villanueva y, posiblemente, a los dos agros y la tierra en Sorbán y a las dos tierras en Torrescas, pues estos dos términos se encuentran atravesados por la "línea de rigidez" del sistema hidráulico ${ }^{146}$. También podríamos añadir los dos agros situados en "Cornu de Caia" y "Cornu Molinelli", respectivamente ${ }^{147}$, si traducimos el vocablo latino "cornu" como "brazo de río". Una importante presencia del cereal también se aprecia en otros espacios de regadío andalusíes. En la huerta de la cercana Tudela, el granizo y la sequía del año 915 provocan un fuerte ascenso del precio del trigo; según Hernández Charro, se trataría de un cultivo anterior a las infraestructuras de riego que aprovecha

141. CANTERA MONTENEGRO, M.: Colección..., doc. 14. "Id est de illo balliolo de Carta usque ad Spino, iuxta rivo molinare; et de alia parte via que dicunt de Acutu partis aquam ab aspecto urbem sitam". UBIETO ARTETA, A.: Cartulario de San Millán..., doc. 235.

142. Ibidem. En 1086 el monasterio de San Millán de La Cogolla encarga construir dos casas en Calahorra sobre un solar "in illo mulatare qui prius fuit parrale, sito extra urbe, iuxta rivo". LEDESMA RUBIO, Ma . L.: Cartulario de San Millán de La Cogolla (1076-1200). Zaragoza, 1989, doc. 121. Seguramente, se refiera al mismo parral recibido del monarca en 1045.

143. LALIENA CORBERA, C.: "El viñedo suburbano de Huesca en el siglo XII". Aragón en la Edad Media, V (1983), pp. 23-44.

144. En 1134, el obispo de Calahorra entrega una era situada "in illas eras de iuso, ubi illo palacio episcopi, et de altera parte sua vinea de los peros". RODRíGUEZ Y RODRÍGUEZ DE LAMA, I.: Colección Diplomática...II, docs. 7, 105 y 106. En un momento indeterminado de la segunda mitad del siglo XI, se cita "una vinea prope illum portellum". CANTERA MONTENEGRO, M.: Colección..., doc. 14.

145. Ibidem, doc. 97.

146. Ibidem, docs. 6, 7 y 29. UBIETO ARTETA, A.: Cartulario de San Millán..., doc. 235.

147. RODRÍGUEZ Y RODRÍGUEZ DE LAMA, I.: Colección Diplomática...II, docs. 6 y 7. 
los mayores rendimientos del regadío ${ }^{148}$. Para Barceló, la presencia del cereal en terrenos regables se debe, no sólo a la posibilidad de alcanzar elevados rendimientos sin precisar abonado, sino también al poco tiempo disponible para el laboreo de los alejados espacios de secano por parte unos campesinos inmersos en el trabajo intensivo del regadío ${ }^{149}$. En la Calahorra islámica, el cultivo del cereal dentro del espacio irrigable queda puesto de manifiesto por la existencia de eras y de molinos, situados sobre las propias acequias de riego, constada en el mismo momento de la reconquista cristiana. Dentro del espacio irrigable también se conservarían masas de bosque de ribera como el "Soto de Algamaga", actual paraje de la Algarrada, topónimo de origen árabe mencionado a finales del siglo $\mathrm{XI}^{150}$.

Junto a la propia ciudad y al río Merdero ${ }^{151}$, se ubica un espacio que combina la producción agrícola con las actividades residenciales y lúdicas; nos referimos a la almunia, o casa de recreo. No la documentamos hasta el año 1222, cuando Fernando III la dona al obispo de Calahorra con "aquis et toto sui iure rigandi"152, y el término "almunia" tiene un significado diferente en las fuentes latinas ${ }^{153}$; a pesar de ello, sí apostamos por su origen islámico. A esta conclusión nos llevan su titularidad regia y el hecho de reunir gran parte de las características de estos espacios andalusíes en virtud de su localización entre la ciudad y el Cidacos, aprovechando la infraestructura de regadío, la vegetación de ribera, así como la protección dispensada por la proximidad de la urbe. Además de lugar de alojamiento de lujo y de retiro para las elites urbanas, se trata también de una explotación agraria, el jardín-huerto o "bustān", donde se cultivan en un regadío intensivo frutas y hortalizas ${ }^{154}$. Del mismo modo, pueden referirse a

148. HERNÁNDEZ CHARRO, M. C.: "Agua y poblamiento..., pp. 321 y s.

149. BARCELÓ, M.: "Saber lo que es un espacio hidráulico..., pp. 78 y ss.

150. Hacia 1100, se cita una pieza ubicada en "la Ponteziella de Soto de Algamaga". RODRÍGUEZ Y RODRÍGUEZ DE LAMA, I.: Colección Diplomática...II, doc. 45.

151. En 1244, se vende un huerto que limita "ex duabus partibus, rivum d'Merdero e...d'quarta parte, alumniam sancte Marie". En 1263, se documenta la compraventa de otro huerto cuyos linderos son "de las dos partes: I'Almunia; de la tercera, el rio de Merdero; de la quarta parte, la Cal del Magoyo". RODRíGUEZ Y RODRÍGUEZ DE LAMA, I.: Colección Diplomática...IV, docs. 150 y 263. En el apeamiento de 1317, que contiene las fincas regadas por el río Merdero, se menciona a dicha Almunia en la primera mitad de su trayecto según salimos de la ciudad. SAÍNZ RIPA, E. y HERNÁEZ IRUZUBIETA, V.: Documentación Calagurritana..., doc. 72.

152. RODRÍGUEZ Y RODRÍGUEZ DE LAMA, I.: Colección Diplomática...III, doc. 484.

153. En las fuentes latinas medievales del espacio ilerdense, "almunia" se identifica con el feudo concedido por el monarca a la pequeña nobleza militar. ERITJA CIURÓ, X.: De l'Almunia a la Turris: organització de l'espai a la regió de Lleida (segles XI-XIII). Lleida, 1998, pp. 16 y s.

154. Almunia sería sinónimo de "el huerto". ASÍN PALACIOS, M.: Contribución a la toponimía árabe de España. Madrid-Granada, 1944, p. 71. SOUTO LASALA, J. A.: "Las ciudades andalusíes: morfologías físicas". Va Semana de Estudios Medievales de Nájera. Logroño, 1995, p. 165. "Munya" designa un lugar de recreo, o sea, una gran casa rural rodeada de dependencias, o si se quiere un cortijo o cortijada". ABD AL-KARIM, G.: Al-Andalus en el "Mu'ŷam alBuldān" de Yãqūt. 1972, p. 38. 
explotaciones agrarias de regadío con elementos residenciales, aunque de menores dimensiones, el "Billari" mencionado en Perenzano hacia 1100, el topónimo Los Villares en "via que vadit ad Soto Dalgarraga", cerca de la citada almunia, y la pieza "que est Villar...in via de Villa Nova"155. Aparte de las acequias, el abastecimiento de agua de estas explotaciones y viviendas lo pueden suministrar las numerosas fuentes y manantiales que afloran en la zona.

La cercanía de los accesos a la ciudad, centro de comercialización y consumo, y las infraestructuras de regadío convierten esta zona en lugar idóneo para actividades de transformación de un cereal, cuya producción también se ubica en gran medida dentro de los campos irrigados. Cerca de la puerta de San Miguel, bajo el puente del Cidacos, se dispone una era ${ }^{156}$. Muy dudosa resulta la ubicación de la "era in Almohala", vocablo que, entre otros significados, puede traducirse por "la posada" o "el barrio"; quizás podríamos identificarlo con el propio arrabal, tratándose de las "areas de illo alfondeck", "eras de Barrio" o "eras de iuso" situadas debajo de él desde la segunda mitad del siglo XI ${ }^{157}$. Respecto a los molinos, su existencia sobre las acequias de riego es algo habitual en la Calahorra islámica; recordemos la denominación de "rivo Molinare" aplicada a uno de estos canales desde el momento mismo de la reconquista en 1045. Además, junto a uno de los accesos de la ciudad, se documenta en 1059 un molino "qui fuit a paganis antiquo"158. Ante la necesidad de disponer de un curso de agua para su funcionamiento, la puerta donde se ubica este ingenio podría ser la Portilla o la puerta de San Miguel, sobre el cauce del río Merdero, o bien la puerta de Arnedo, aprovechando las aguas del río Mencabla; cobra más fuerza esta última opción si lo identificamos el "molendino qui dicitur Vencabla in porta d'Arnedo" documentado dos siglos después ${ }^{159}$. Más alejado de la urbe, aprovechando también el cauce del "rivo Molina$r e^{\prime \prime}$, se encuentra el molino que la documentación cristiana llama de San Felices o de "Diacanga de Albelda"160. Aunque resulta habitual la presencia de "industrias polucionantes" (curtidos, cerámica,...) relegadas a estos espacios periurbanos, por razones obvias, y localizamos curtidores junto al río Merdero en el siglo XVII ${ }^{161}$, carecemos de información acerca de estas actividades para el momento islámico.

155. RODRÍGUEZ Y RODRÍGUEZ DE LAMA, I.: Colección Diplomática...II, docs. 45 y 99.

156. "ante villa in via de Acuto, de sinistra parte sub ponte". UBIETO ARTETA, A.: Cartulario de San Millán..., doc. 235.

157. ASÍN PALACIOS, M.: Contribución..., p. 69. RODRÍGUEZ Y RODRÍGUEZ DE LAMA, I.: Colección Diplomática...II, docs. 99, 105 y 106. CANTERA MONTENEGRO, M.: Colección..., doc. 14.

158. UBIETO ARTETA, A.: Cartulario de San Millán..., doc. 305.

159. RODRÍGUEZY RODRÍGUEZ DE LAMA, I.: Colección Diplomática...IV, docs. 146 y 164.

160. El 1 de agosto de 1062, el monasterio de San Martín de Albelda entrega a censo "illum molinum de Sancti Felicis de Calagurra, qui est nominatum de Diacanga de Albelda". UBIETO ARTETA, A.: Cartulario de Albelda..., doc. 45.

161. En 1653, el Hospital de Labradores Pobres de la ciudad de Calahorra se querella contra los curtidores por obstaculizar el curso del río Merdero y, con ello, provocar la inundación de sus edificios. REYES MANZANO, A.: Mandar es Juzgar..., p. 79. 


\subsection{El campo abierto}

Más alejado de la ciudad, fuera del terreno afectado por las acequias, generalmente por encima de la "línea de rigidez" establecida por éstas, se extiende el denominado "campo abierto". Un espacio donde la ocupación humana del espacio es menos intensa, centrada en actividades predatorias y agrarias extensivas, y la influencia de la ciudad se diluye, manifestándose sólo mediante expediciones fiscales periódicas y el mantenimiento de un sistema de defensa. Así, encontramos espacios de cultivo cerealista como las dos tierras en Almudebar $^{162}$, que deben ser parcelas de secano, pues se encuentran por encima de la "línea de rigidez" del sistema hidráulico; lo mismo ocurriría con las actividades agrarias desarrolladas en el término de "Albarrueque", "Albarruet", "Alvareque" o "Albarbuek", topónimo de origen árabe, documentado desde 1132 y situado por encima del río de Sorbán ${ }^{163}$.

Donde no llegan las roturaciones cerealistas, permanece la vegetación autóctona de matorral o las masas boscosas de ribera como el "Soto de Ortest" ${ }^{\prime 164}$, lugares idóneos para una explotación pastoril y actividades predatorias (recolección, caza, obtención de madera,...). Un caso especial viene dado por el "Soto de Olivo", mencionado en 1084 ${ }^{165}$, quizás un dato de la práctica de una arboricultura silvestre en estos espacios forestales de ribera. Apenas hemos encontrado otra información respecto al olivar, cultivo que debió extenderse por zonas marginales, por encima del espacio irrigable, seguramente sobre la meseta que se eleva en el actual paraje de Las Planillas, a tenor de la

162. Quizás también sean parcelas de secano los dos agros y la tierra en Sorbán y las dos tierras en Torrescas, pues estos parajes se extienden a ambos lados de dicha "línea de rigidez". RODRÍGUEZ Y RODRÍGUEZ DE LAMA, I.: Colección Diplomática...II, docs. 6, 7 y 29. UBIETO ARTETA, A.: Cartulario de San Millán..., doc. 235.

163. RODRÍGUEZY RODRÍGUEZ DE LAMA, I.: Colección Diplomática...II, doc. 99. Colección Diplomática...IV, docs. 468, 485 y 486. SAÍNZ RIPA, E. y ORTEGA LÓPEZ, A.: Documentación Calagurritana del siglo XV. Archivo Catedral. Logroño, 2004, doc. 7.

Quizás se trate de un secano itinerante sin barbecho, similar al empleado en zonas del Magreb Apoyando esta hipótesis, los documentos inmediatamente posteriores a la reconquista cristiana sobre los espacios de cereal nos transmiten la imagen de una explotación extensiva ya que se denominan "agro" o "terra", términos de carácter ambiguo e impreciso y sólo en una ocasión sus linderos se refieren a otros espacios de cultivo. Sin embargo, esta débil intensidad se da tanto en los espacios cerealistas de secano como en los de regadío. BARCELÓ, M.: "Saber lo que es un espacio hidráulico..., p. 83. SALAS DUQUE, D.: "Terminología de la producción y organización de los espacios de cereal en La Rioja en los siglos X a XIII". Segundo Coloquio sobre Historia de La Rioja. Logroño, 1986, pp. 290 y ss. GARCíA FERNÁNDEZ, E.: Santa María de Irache: Expansión y crisis de un señorío monástico navarro en la Edad Media (958-1537). Bilbao, 1989, p. 95.

164. En 1074, se localiza un agro en "soto de Ortest, in termino de Almoddobar". RODRíGUEZ Y RODRÍGUEZ DE LAMA, I.: Colección Diplomática...II, doc. 29.

165. GOÑI GAZTAMBIDE, J.: Colección Diplomática..., doc. 34. 
mención a una "via de Olivo" que atraviesa el término de Sorbán a finales del siglo $\mathrm{XI}^{166}$. A partir del análisis de la toponimia de origen árabe, podemos intuir en este "campo abierto" actividades extractivas, posiblemente alguna de las vetas de cal, yeso o de los afloramientos salinos habituales en la zona; en concreto, nos referimos al topónimo "Almagaden"167, cuya localización exacta ignoramos, que provendría del vocablo árabe "al-mádin", la mina ${ }^{168}$. Asimismo, el actual paraje Falfarracín, en caso de derivar de "Alfarazín", o "los caballos", nos informaría de una actividad ganadera íntimamente ligada con las necesidades militares de un establecimiento fronterizo ${ }^{169}$.

La propia lejanía de la ciudad respecto de los cultivos de secano, y de parte de los de regadío, así como la articulación de un sistema de posiciones defensivas frente a las cercanas posiciones cristianas, configuran una serie de asentamientos dispersos en este sector del campo calagurritano. Entre estas posiciones debemos diferenciar entre aquellas que, generalmente en torno a una posición defensiva o torre de vigilancia, acogen una población estable que trabaja una explotación agraria de carácter acotado, de las pequeñas atalayas defensivas destinadas a meras labores de vigilancia y de comunicación por señales, carentes de una dimensión mínima para albergar una guarnición permanente ${ }^{170}$.

Comenzamos hablando de las poblaciones rurales que aúnan misiones de vigilancia y labores de explotación agraria, tipología donde podemos incluir los siguientes asentamientos:

- "Almonezer", "Almonasterio" o "Almonazer". Situado al noroeste de Calahorra, ignoramos su localización exacta; no obstante, los parajes que forman su término nos permiten ubicarlo más concretamente al norte de la calzada romana sobre algunos de las terrazas existentes frente a la ribera del Ebro. Su primera mención es la "via de Almonezer" en $1046^{171}$, teniendo que esperar hasta 1084 para localizar allí viñas y tierras donadas por el conde García Ordóñez al monasterio de San Adrián

166. RODRÍGUEZ Y RODRÍGUEZ DE LAMA, I.: Colección Diplomática...II, doc. 45.

167. Ibidem, doc. 281.

168. "Almaden: Es en España pueblo del arzobispado de Siuilla, y es también otro pueblo del obispado de Calahorra. Consta de "al" que en arábigo significa el, y de "mádin", que significa minero o veta de algún metal..." GUADIX, D. de: Recopilación..., p. 285. En catalán se registran las formas "Almaagdan" y "Almaaden". STEIGER, A.: Contribución a la fonética del hispano-árabe y de los arabismos en el ibero-románico y el siciliano. Madrid, 1991, p. 286.

169. "Alfarazín o Alfaraçín: Es en España pueblo del reyno de Valencia. Consta de "al", que en arábigo significa "los", y de "farazín", que significa cauallos, assi que todo junto, Alfarazín significa los cauallos..." GUADIX, D. de: Recopilación..., pp. 252-253.

170. Establece esta diferencia entre las fortificaciones islámicas en torno a Tudela. BIENES CALVO, J. J.: "Fortificación islámica en el valle medio del Ebro". Cuando las horas primeras. En el milenio de la batalla de Calatañazor. Soria, 2002, pp. 285-295.

171. RODRÍGUEZ Y RODRÍGUEZ DE LAMA, I.: Colección Diplomática...II, docs. 7 y 45. 
de Palma ${ }^{172}$; en 1100, confirma su carácter de explotación agraria al acoger la heredad entregada por doña Eugenia a la catedral de Calahorra' ${ }^{173}$. Etimológicamente, su nombre proviene de "al monastīr", pudiendo desempeñar una función de "ribāt" , es decir, un espacio defensivo con población más o menos permanente, que se emplea como base de operaciones militares de grupos irregulares y/o lugar de retiro religioso ${ }^{174}$. Epalza sí considera viable esta identificación, haciendo derivar el término de la localidad tunecina homónima ${ }^{175}$; al contrario, Jiménez Martín, Asín Palacios y Martínez Salvador creen que la palabra "monastīr" se refiere a un previo establecimiento religioso cristiano ${ }^{176}$. Se trate o no de un "ribāt", su localización al noroeste de la ciudad, cerca de la calzada romana y, sobre todo, frente a Resa confirmarían su carácter de posición defensiva, pues esta localidad es una avanzadilla del reino pamplonés desde mediados del siglo $X^{177}$ en el cruce del Ebro hacia Sartaguda y Carcar, lugar de la batalla de Palma en el 842 y ruta seguida por las expediciones de 'Abd al-Raḥmān III ${ }^{178}$.

- "Almudebar", "Almodebar", "Almudevariel" o "Campo de Almudevar". En función de los datos documentales ${ }^{179}$, lo localizamos en el actual para-

172. GOÑI GAZTAMBIDE, J.: Colección Diplomática de la Catedral de Pamplona (8291243). Pamplona, 1997, doc. 34.

173. RODRÍGUEZ Y RODRÍGUEZ DE LAMA, I.: Colección Diplomática...II, doc. 45.

174. Inicialmente, era el lugar de reunión de las monturas para una expedición armada. MARÍN, M.: "La práctica del ribat en Al-Andalus". La rábita califal de las dunas de Guardamar (Alicante). Alicante, 1989, pp. 191 y s.

175. EPALZA, M. de: "La Rápita islámica: Historia institucional". La Rábita en el Islam: Estudios interdisciplinares: congresos internacionales de Saint Carles de la Rápita (1989, 1997). Alicante, 2004, p. 102.

176. MARTÍNEZ SALVADOR, C.: "Sobre la identidad de la rábita andalusí omeya". La rábita califal de las dunas de Guardamar (Alicante). Alicante, 1989, pp. 184 y s. ASÍN PALACIOS, M.: Contribución..., p. 70. De los muchos topóminos derivados de "monastīr" sólo en uno cercano a Belchite está documentada la práctica del "ribāṭ". Además, esta actividad religioso-militar resulta poco habitual en al-Andalus, donde el control de la frontera depende de poderes locales o centrales. MARíN, M.: "La práctica del ribat..., pp. 199 y s.

177. En 950, la donación de los monjes de Laturce al abad de San Martín de Albelda tiene lugar "in margine fluminis Ibero qui Arrezo, in Sancta Eulalia". GARCÍA TURZA, F. J.: Documentación medieval del Monasterio de San Prudencio de Monte Laturce (siglos X-XV). Logroño, 1992, doc. 1. En 970, el monarca pamplonés Sancho Garcés confirma una donación a San Millán de la Cogolla "in concilio de Sancta Eulalia, in Arrezo". UBIETO ARTETA, A.: Cartulario de San Millán..., doc. 87.

178. LACARRA, J. M.: "Expediciones Musulmanas contra Sancho Garcés (905-925)". Príncipe de Viana, I (1940), pp. 56 y 67. Es el Ilamado "vado de Resa", punto de tradicional de paso del Ebro que podía estar relacionado con la red viaria romana, denominado "navigio de Palma" en los primeros documentos tras la conquista cristiana. PASCUAL MAYORAL, M. P. y GARCÍA RUÍZ, P.: "Las comunicaciones..., p. 34. CANTERA MONTENEGRO, M.: Colección..., doc. 14.

179. Se encuentra en una zona, el "Badello Petroso", pedregosa y de relieve desigual con tierras incultas, adyacente al "rivo de Siest", a "illa lacuna" y al "Valadar de la lacuna" y cerca 
je de Torre de Campobajo, zona de asentamiento humano desde la edad del Hierro hasta el momento medieval'180. Derivaría de "al mudawwar", que significa "el redondo"181, característica que todavía conserva en la actualidad, por lo que suponemos se refiere a un espacio cerrado o acotado. Más aun cuando sabemos que allí existía una explotación agraria organizada desde una torre que, hacia 1100, Alfonso VI dona a Maingo "cum suis exteris et intratis et cum suis terminis" y, de la misma manera, Alfonso I entrega a Fortún Aznarez de Medina "illa Torre de Almudebar cum totis terminis suis ermis et populatis qui pertinent ad ista supradicta Torre" en $1132^{182}$. Dicha explotación, situada justo por encima del río Molinar, se centra en el cultivo del cereal (alberga dos tierras en 1074 ${ }^{183}$ ), pero con un carácter discontinuo a tenor de la referencia a espacios incultos, entre ellos, el "Soto de Ortest", susceptible de aprovechamiento ganadero y/o forestal ${ }^{184}$. Su cercanía a la calzada romana y su comunicación visual con el alcázar calagurritano confirman el carácter estratégico de esta torre.

- "Tore dAlbogozan". En 1132, se localiza allí una pieza; su denominación como "torre" y la posible derivación de "Albogozan" a partir de la forma "Abū Gen", etimología reveladora de su propietario, nos lleva a atribuirle el rango de gran explotación rural o cortijada, a pesar de no contar con más datos al respecto ${ }^{185}$. No ha sido posible situarla cartográficamente.

- San Felices de Bea. Este asentamiento, situado en la orilla izquierda del Cidacos en el camino que lleva a Autol ${ }^{186}$, cuenta con registros arqueológicos altomedievales, sobre todo restos de una necrópolis, uno de cuyos sarcófagos podría ser de época visigótica ${ }^{187}$. En 1062, San Martín de Albelda da en censo el molino de San Felices Ilamado "Diacanga de

de la calzada romana. RODRÍGUEZ Y RODRÍGUEZ DE LAMA, I.: Colección Diplomática....II, doc. 124. Colección Diplomática...III, docs. 280-b, 248 y 438.

180. VV. AA.: Miscelánea..., p. 277. Aunque todavía se distingue sobre el terreno, desgraciadamente la elevación fue desmochada en los años setenta.

181. STEIGER, A.: Contribución..., p. 361. ASÍN PALACIOS, M.: Contribución..., p. 71.

182. RODRÍGUEZ Y RODRÍGUEZ DE LAMA, I.: Colección Diplomática...II, docs. 47 y 101. "Almudébar: Es en España pueblo del obispado de Güesca, en Aragón. Es la mesma algarabía y significa lo mesmo qu'el nombre Almodóvar... Consta de al, que, en arábigo, significa el, y de mudabir, que significa governador, regidor o corregidor; de suerte que todo junto, almudabir significa el governador, el regidor o el corregidor...". GUADIX, P. de: Recopilación..., pp. 298 y 305.

183. RODRÍGUEZ Y RODRÍGUEZ DE LAMA, I.: Colección Diplomática...II, doc. 29.

184. Ibidem.

185. Ibidem, doc. 99

186. ELÍAS PASTOR, L. V.: "Los despoblados riojanos". Apuntes de Etnografía riojana, II. pp. 78 y s.

187. VV. AA.: Miscelánea..., pp. 10 y s. URBANO ESPINOSA: Calagurris..., p. 321. LUEZAS PASCUAL, R. A.: "Introducción al estudio de las necrópolis medievales de La Rioja". Boletín de Arqueología Medieval, XI (1997), p. 214. 


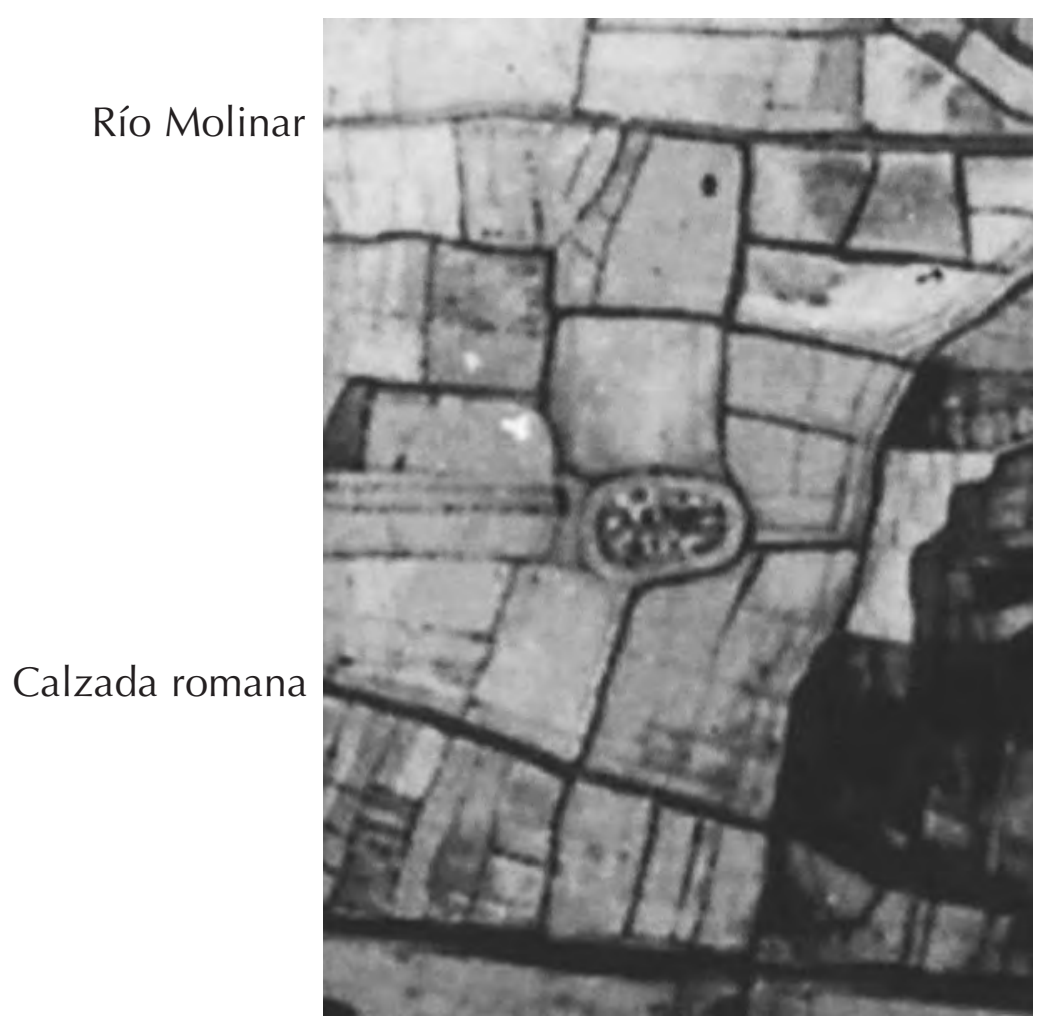

Vista aérea de la Torre de Campobajo. Foto Bella.

Albelda"188. Aunque resulte arriesgado, podemos situar aquí también la "domum...cum suis exitis, terris, vineis et ortis" exenta de la jurisdicción del señor de Calahorra que, hacia esa misma fecha, el infante don Ramiro Garcés dona a este mismo monasterio ${ }^{189}$.

- Villanueva: En 1045, justo en el momento reconquistador ya se menciona la "via de Vila Nova" y, al año siguiente, el propio poblado situado al este de la ciudad en una segunda terraza frente al Ebro ${ }^{190}$; además, se ha

188. UBIETO ARTETA, A.: Cartulario de Albelda..., doc. 45.

189. "ingenuam hac liberam eam habeatis in omni vita vestra, ita ut nullus señor qui dominatus fuerit Calagurre sit ausus inquietare vos insuper predicta domum". Ibidem, doc. 44.

190. UBIETO ARTETA, A.: Cartulario de San Millán..., doc. 235. RODRÍGUEZ Y RODRÍGUEZ DE LAMA, I.: Colección Diplomática...II, doc. 7. LUEZAS PASCUAL, R. A.: "Introducción..., p. 212. 
excavado allí una necrópolis seguramente bajoimperial. Por tanto, aunque su etimología nos remite a una iniciativa repobladora de la monarquía pamplonesa, pudo existir algún tipo de asentamiento en época islámica.

Un caso muy dudoso sería el de la "Almohala", vocablo puede traducirse por "la posada", "el barrio" o bien referirse a un "campamento temporal" como la "maḥalla" de Calahorra donde 'Abd al-Raḥmān III recibe a la reina Toda de Pamplona en el $934^{191}$. En 1045, se localiza allí una era ${ }^{192}$ y hemos propuesto identificarlo con el propio arrabal calagurritano que, como ya hemos visto, también acoge otros espacios de transformación de la producción agraria. Otra posibilidad nos la ofrece un pergamino de principios del siglo XII que menciona en Resa una pieza "in cuna de monte, latus via de Almohalla"193, es decir, dicha "Almohala" se ubicaría a cierta distancia de la urbe y sobre un desmonte del terreno, seguramente por encima de la línea de rigidez del sistema hidráulico, siendo un asentamiento de ocupación discontinua en función de las distintas labores agrarias ${ }^{194}$ o refiriéndose al propio Almonecer, cuya realidad topográfica resulta similar.

Varios de estos asentamientos se hallan acotados y cuentan con elementos defensivos, las torres de Almudebar y Albogozan, así como el supuesto "ribāt" de Almonecer. La finalidad de estas torres es tanto la protección de las explotaciones agrarias y de sus trabajadores, así como la alerta de la propia Calahorra. Incluso el vocablo "torre" llegó a sufrir un cambio semántico en ciertas regiones españolas tras la reconquista cristiana; así, en Aragón significa a la vez un edificio defensivo, una casa de labor y una propiedad de regadío ${ }^{195}$. Como también resulta habitual en el Islam hispano, estos núcleos de población se sitúan fuera, o en los límites, del espacio irrigado por la acequia Madre de Sorbán y el río Molinar y, a menudo, por encima de la "línea de rigidez" definida por estos cauces ${ }^{196}$. Las razones resultan obvias: no competir por el espacio con la agricultura intensiva de regadío, evitar posibles avenidas y mantener una preeminencia visual de cara a

191. ASÍN PALACIOS, M.: Contribución..., p. 69. Del mismo étimo es almohalla, "puente donde descansan las vigas del techo" (anz.) por metonimia. CORRIENTE, F.: Diccionario de arabismos y voces afines en iberorromance. Madrid, 1999, p. 184. VIGUERA, M. J. y CORRIENTE, F.: Crónica del califa Abderramán III..., p. 252.

192. UBIETO ARTETA, A.: Cartulario de San Millán..., doc. 235.

193. LEDESMA RUBIO, M ${ }^{a}$ L.: Cartulario..., doc. 505.

194. En portugués "almofalla" o "almofala" significa "campo, arraial em que se reside algum tempo". STEIGER, A.: Contribución..., p. 263.

195. SOUTO LASALA, J. A.: "Contribución al estudio del poblamiento del término de Zaragoza en época Omeya". La marche superiéure d'al-Anmdalus et l'Occident chrétien. Madrid, 1991, p. 124.

196. BARCELÓ, M.: "El diseño de los espacios irrigados..., p. 62. KIRCHNER, E. y NAVARRO, C.: "Objetivos, métodos y práctica..., pp. 100 y s. 
sus labores de vigilancia. Por tanto, constituyen explotaciones agrarias, basadas en cultivos de regadío y/o de secano, así como en las actividades ganaderas y predatorias posibles en los cercanos espacios de vegetación natural.

Esta doble actividad agrario-militar exige una continua presencia de población. Hemos señalado la existencia de fases de habitación preislámica en muchos de ellos. La documentación latina nos permite intuir esta población permanente en el caso de Villanueva, en función de la etimología del topónimo, y Almonecer, considerado a principios del siglo XII "vichum" y "villa", denominaciones que afirman su carácter de núcleo de población asimilable a una aldea ${ }^{197}$. Estos lugares ofrecerían a sus habitantes la comodidad en la explotación económica del territorio gracias a la cercanía a los recursos, la seguridad derivada de sus torres y, quizás, la huída de la mayor presión fiscal existente en la ciudad. Estos núcleos de población menores organizan un pequeño territorio o "termino" en torno a sí, ciñéndose quizás a los límites de la propia explotación agraria. En 1074, el monarca pamplonés Sancho Garcés IV dona dos tierras "in soto de Ortest in termino de Almoddobar"198. Diez años más tarde Almonecer es mencionado como una realidad diferente y al mismo nivel que Calahorra ${ }^{199}$ y, en 1132, se citan varios parajes de su término; algunos de ellos como "Corrigia Longa", "Bergal" y "Meçaniello" se pueden identificar con los topónimos actuales de Corrigotas, el Vergal y Manzanillo, respectivamente ${ }^{200}$. Por último, hacia 1132, la catedral de Calahorra posee una pieza "in termino de Tore d'Albogozan"201. Estas poblaciones se articulan en función de un lugar cen-

197. "in vicho de Almonecer in locum Spiluencha". RODRÍGUEZ Y RODRÍGUEZ DE LAMA, I.: Colección Diplomática...III, doc. 390. Durante los siglos X y XI, la denominación "vicus" en el espacio riojano se asimila a la "villa". Aunque durante la centuria anterior fuesen explotaciones en coto redondo, ya en el siglo XI las "villae" riojanas se asimilan a aldeas o asientos de comunidades campesinas con algunas capacidades propias. GARCÍA DE CORTÁZAR, J. A.: "Los comienzos de la organización hispanocristiana del espacio riojano entre los años 923 y 1016". Historia de la Ciudad de Logroño, II: Edad Media. Logroño, 1994, p. 69. En 1084 García de Almonecer es puesto al frente del monasterio de San Adrián de Palma por el conde García Ordoñez, en 1110 Julián de Almonecer recibe una donación de la reina castellana doña Urraca y, medio siglo después, Lope García de Almonecer entrega a la catedral su casa con atrio allí situada. Quizás también se refieran a esta población los nombres de "Petro de Almokerr" o "de Almocher" o "de Almoquer" y de "Garcia Almonecera", documentados en Calahorra durante el último tercio del siglo XII. GOÑI GAZTAMBIDE, J.: Colección Diplomática..., docs. 34 y 123. RODRÍGUEZ Y RODRÍGUEZ DE LAMA, I.: Colección Diplomática...II, docs. 83d y 214. Colección Diplomática...III, docs. 248, 267, 311, 387 y 401.

198. En su donación por parte de Alfonso I "el Batallador" en 1132 se explicita "...illa Torre de Almudebar cum totis terminis suis ermis et populatis qui pertinent ad ista supradicta Torre...". Hacia 1145, se dona una pieza "in termino de Almudevar, in Vado Petrocoso". RODRÍGUEZ Y RODRÍGUEZ DE LAMA, I.: Colección Diplomática...II, docs. 29, 101 y 124.

199. Situación que se repite en 1110. GOÑI GAZTAMBIDE, J.: Colección Diplomática..., docs. 34 y 123.

200. Ibidem, doc. 148.

201. RODRÍGUEZ Y RODRÍGUEZ DE LAMA, I.: Colección Diplomática...II, doc. 99. 
tral, la ciudad de Calahorra, dependencia queda explicitada en el caso de Almudebar al donarla Alfonso I "el Batallador" a Fortún Aznarez de Medina en 1132 ${ }^{202}$.

En definitiva, nos encontramos ante una realidad similar a la observada por Eritja Ciuró en el campo de Lérida durante los siglos XI y XII, es decir, salpicada de "diyā", aldeas o explotaciones rurales que la documentación latina denomina "turris", "almunia" o "grangia", subordinadas a un "hiṣn" o "madīna" y que disponen de su propio término ${ }^{203}$. Lo mismo observa Sénac en los asentamientos andalusíes al norte del Ebro y, además, apuntando que no hay un "incastillamento", pues no existe un reagrupamiento de la población en torno a un núcleo fortificado, sino una fortificación de los asentamientos dispersos, algunos de ellos existentes desde época prerromana, en el entorno rural de un núcleo de población principal ${ }^{204}$.

Respecto a las atalayas de observación sin una guarnición permanente y desvinculadas de explotaciones agrarias, el mejor ejemplo nos lo ofrece el paraje del Portillo de Tudelilla, cerca del término "el Almenar", al suroeste de la ciudad, donde se han hallado restos de cerámica islámica de los siglos VIII y IX que permiten intuir la existencia de un punto de vigilancia en este acceso al valle del Cidacos $^{205}$. En razón de su topografía y ubicación respecto de Calahorra y la calzada romana, las localizaciones de Cabezo de la Torre ${ }^{206}$, al sudeste de la ciudad, en el actual término de Aldeanueva de Ebro, y de Cabezo de la Cruz, al noroeste de la urbe, también pudieron albergar algunas de estas torres vigías; no obstante, los materiales que se aprecian en superficie, aún relativos a la época medieval, no resultan determinantes al respecto. Puede ser el mismo caso de topónimos recogidos en la documentación inmediatamente posterior (hasta mediados del siglo XII) como "Torreschas"207, "illa Torricella"208 y "Turrem de

202. "...in Calahorra illa Torre de Almudebar...". Ibidem, doc. 101. En 1172, el propio concejo de Calahorra dona a Salito una tierra en "Campo de Almudevar". RODRÍGUEZ Y RODRÍGUEZ DE LAMA, I.: Colección Diplomática...III, doc. 248.

203. ERITJA I CIURÓ, X.: "Entre la Lleida andalusí i la feudal (segles XI-XII). Un model d'explotació rural"., pp. 25 y ss.

204. "..., il est impossible de parler d'incastellamento dans la mesure oú l'on n'assiste à aucun regroupement autoritaire des populations". SÉNAC, Ph.: "Stratigraphie..., pp. 66 y s.

205. ANTOÑANZAS SUBERO, A.: "Restos arqueológicos en el Portillo de Tutelilla". Kalakorikos, II (1997), pp. 285-292. El topónimo "Almenar" se puede traducir por "la atalaya". ASíN PALACIOS, M.: Contribución..., p. 68.

206. La documentación del siglo XIV lo menciona como el "Cabeço del Atalaya sobre el cabeço que dizen de Muño Sanchez". SAÍNZ RIPA, E. y HERNÁEZ IRUZUBIETA, V.: Documentación Calagurritana..., docs. 228 y 229.

207. En 1074, Sancho Garcés IV dona dos tierras en "Torreschas". RODRÍGUEZ RUÍZ DE LAMA, I.: Colección Diplomática...II, doc. 29.

208. Ibidem, doc. 113. En la Torrecilla existió un asentamiento romano localizado junto a la presa de la Degollada. PASCUAL MAYORAL, M. P. y GARCÍA RUÍZ, P.: "El abastecimiento..., pp. 55 y ss. 
Salamaias" ${ }^{209}$, al mediodía de Calahorra, y del "molino de la Turre"210, cuya localización ignoramos. Ya hemos visto a qué realidades poblacionales islámicas puede referirse el vocablo "torre" tras la reconquista cristiana; sin embargo, ante la escasez de datos, no podemos decir nada más.

Para su función de vigía, estas atalayas, y las torres anteriormente citadas, precisan de una comunicación visual con la alcazaba calagurritana, hecho constatado para todas aquellas cuya ubicación exacta conocemos. Las tareas de vigilancia resultan esenciales para las cotidianas acciones militares de los "țugür", consistentes en rápidos golpes de mano donde la información resulta clave para efectuar tanto un acción por sorpresa como una retirada a posiciones seguras minimizando los daños de las incursiones enemigas ${ }^{211}$. Aparte de la información, la movilidad es otro elemento indispensable dentro de una escaramuza exitosa; de ahí, la importancia de la caballería y de los espacios dedicados a su cría en este "campo abierto", realidad que nos permite intuir el topónimo "Falfarracín". De este modo, queda dibujado un sistema defensivo similar al de los entornos rurales de ciudades andalusíes como la cercana Tudela, es decir, salpicado de aldeas, con sus propios "burug" o torres, y de meras atalayas de observación ${ }^{212}$.

\subsection{Una interpretación social de la organización del espacio rural en la Calahorra islámica}

Hasta ahora, con mayor o menor éxito, hemos pretendido esbozar la organización económica de los espacios urbanos y rurales de la Calahorra islámica. La escasez de datos y la dificultad para interpretar una información recogida "a posteriori" por la documentación latina dan lugar a situaciones frustrantes; sirva como ejemplo la imposibilidad de localizar muchos topónimos de origen árabe (p.e. "Almagaden", "Albogozan", "Amohabaç"213,...). A continuación, lastrados con las mismas carencias informativas, planteamos algunas hipótesis

209. En 1151, el concejo de Calahorra dona a la Catedral una "terram incultam in termino prefate civitatis ad meridiem, qui vocatur Spartal de Salamanas... ab oriente, via que ducit Alfarum, deinde Tutelam... ab occidente, via que ducit Turrem de Salamaias". En función de esta cita y, asumiendo la etimología propuesta por Rodríguez de Lama a partir de "salem manare", localizamos dicha torre en cualquiera de los afloramientos salinos existentes al sur de Calahorra, relativamente cerca de la calzada romana. RODRÍGUEZ RUÍZ DE LAMA, I.: Colección Diplomática...ll, doc. 155.

210. El dato más ilustrativo es la ubicación de una viña "circa illa Turre, ubi illo molino episcopi" en 1132. Ibidem, docs. 81, 102 y $124 \tilde{n}$.

211. En el año 940 llega a Toledo el "qā 'id Ahmad b. Muḥammad b. Ilyās, para combatir a los enemigos de Dios..., atalayar sus comarcas y observar sus fronteras". CHALMETA, P.: "El concepto..., pp. 24 y s.

212. BIENES CALVO, J. J.: “Fortificación..., pp. 285-295. HERNÁNDEZ CHARRO, M. C.: "Agua y poblamiento..., p. 327.

213. RODRÍGUEZ Y RODRÍGUEZ DE LAMA, I.: Colección Diplomática...II, doc. 188. Colección Diplomática...III, doc. 281. 
E Hisn Qsahum

S Arrabal

L Wa de Almenecer"

II.

Iv. "Via de Acuto"

v. "Va que ducil Abtanium"

Q Torre

NUTOL Raino de Pamplona

* vilares

a Almunia
Catzada "Tarraco - Aaturtea Augueata"

$$
\text { m }
$$

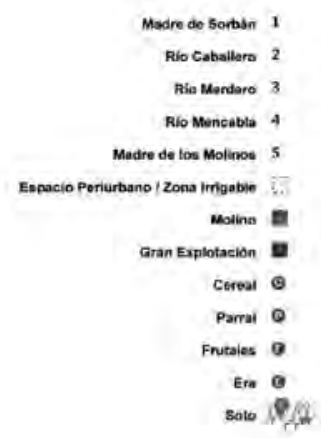

Madre de 5orbin 1

Rio Caballars 2

Ris Merdaro 3

Rio Mencibla 4

(6)

putaies 0

sole 1 .

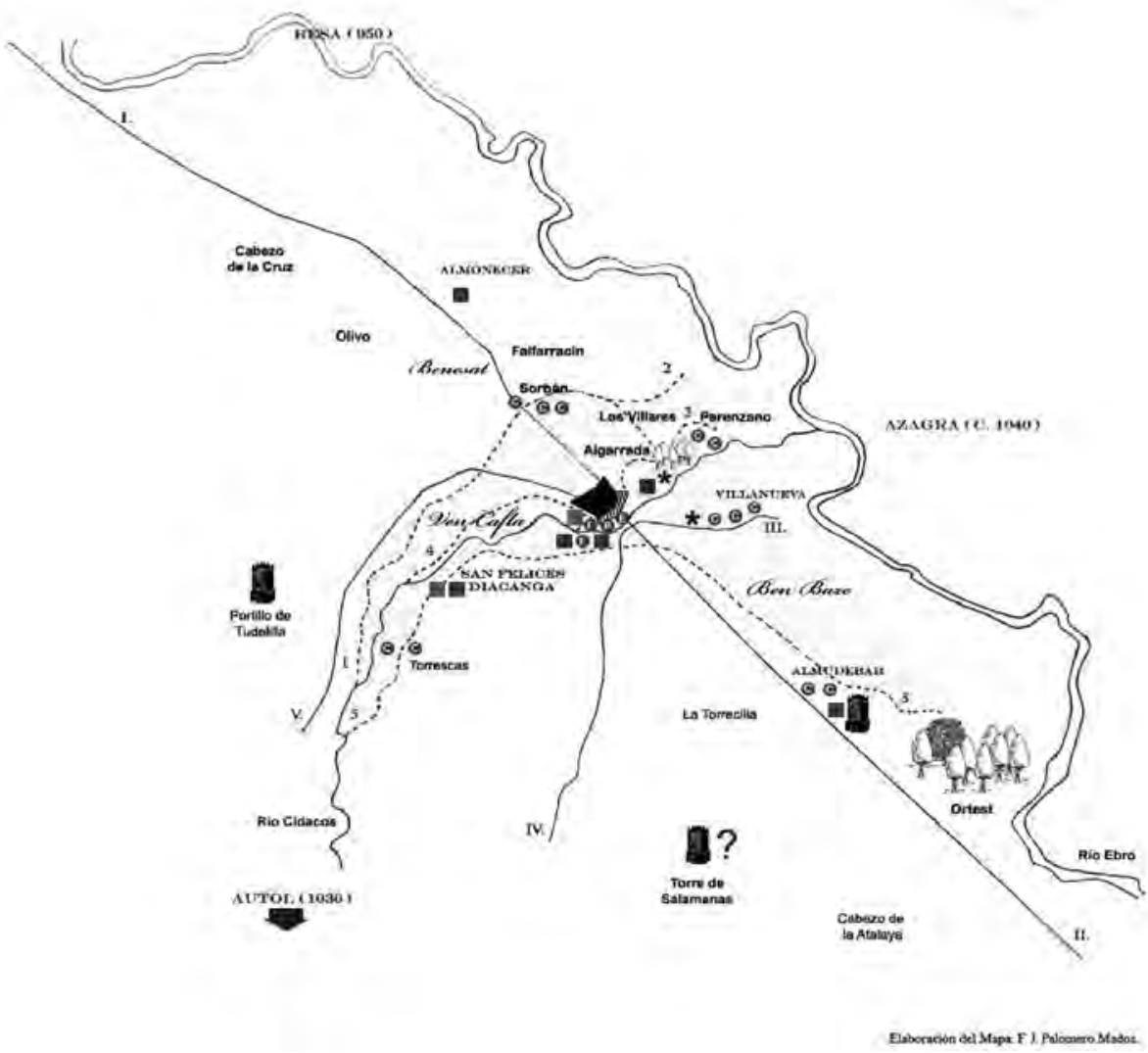

Organización del espacio rural en la Calahorra islámica 
acerca del componente social en la organización del espacio rural de la Calahorra andalusí.

Una vez más recordamos el año 968, momento de la última recuperación de la ciudad por parte de los cordobeses, inicio de casi ochenta años de estabilidad que permiten a Calahorra superar un inmediato pasado de inseguridad, saqueos y despoblación. La recuperación demográfica y el desarrollo de una agricultura intensiva de regadío favorecen el crecimiento físico de la urbe, evidenciado en la configuración del arrabal junto al río Cidacos y sobre el trazado de un cauce de riego, el río Merdero. El origen de estas infraestructuras hidráulicas de regadío se halla en la propia presión demográfica, que estimula un aumento de los rendimientos agrícolas ${ }^{214}$. Barceló identifica a los creadores de los sistemas hidráulicos andalusíes como comunidades campesinas regidas por un orden político basado en la genealogía, es decir, grupos familiares extensos o clanes que comparten gran parte de sus propiedades, existiendo, por tanto, una escasa diferenciación social dentro de ellos. Una evidencia de esta autoría sería la propiedad y la autorregulación colectivas de estas infraestructuras hidráulicas a base de turnos o tandas; realidad conservada hasta nuestros días en muchos regadíos españoles ${ }^{215}$. Asimismo, la explotación de los espacios de regadío también puede responder a una estrategia de estas comunidades campesinas, pues el "cultivo promiscuo" practicado en estas superficies genera productos, en su mayor parte fugaces y no acumulables, válidos para garantizar su autoabastecimiento, pero sin generar excedentes fiscalizables; esta ausencia de excedentes también permite mantener la homogeneidad social de dichas comunidades campesinas ${ }^{216}$. En el regadío calagurritano, observamos prácticas comunitarias que pueden remitirnos a dicho origen. Nos referimos a la regulación por horas del aprovechamiento del agua ${ }^{217}$ y a la propia etimología de la palabra "jeriganza", o comunidad de regantes, ejemplos de un reparto individual al explotar una realidad comunitaria. Además, aunque fuera del espacio de nuestro estudio, en la vecina localidad de Azagra, documentamos la construcción de una acequia por parte de los propios vecinos en $1084^{218}$.

214. BARCELÓ, M.: "La cuestión del hidrualismo andalusí". El agua que no duerme. Granada, 1996, p. 17.

215. BARCELÓ, M.: "El diseño de los espacios irrigados..., pp. 55 y ss. "Saber lo que es un espacio hidráulico..., pp. 75 y ss.

216. BARCELÓ, M.: "El diseño de los espacios irrigados..., p. 62. KIRCHNER, E. y NAVARRO, C.: “Objetivos, métodos y práctica..., pp. 93 y s.

217. Sobre la regulación del agua del Cidacos por horas de aguadas durante la Edad Moderna, sirva como ejemplo el pleito de la ciudad de Calahorra con las villas de Aldeanueva y Rincón de Soto. REYES MANZANO, A.: Mandar es Juzgar..., pp. 224-228.

218. "in Sotolga iuxta rivo quod aperuerunt vicinos". GOÑI GAZTAMBIDE, J.: Colección Diplomática..., doc. 34. 
La presencia de comunidades campesinas organizadas como grupos gentilicios se puede rastrear en la toponimia calagurritana; los términos "campo de Benesate o de Benesat"219 y, en menor medida"20, los de "Ben Cafla, Vencabla o Ben Caubla"221 y "foveam de Vembaço"222 son posibles derivaciones de patronímicos con prefijo "Beni-" como los estudiados por Pierre Guichard. A diferencia de los patronímicos con prefijo "Avin" referidos a un individuo concreto, este autor considera que revelan extensos grupos familiares, inferiores a la tribu y similares a clanes, con gran peso de la propiedad colectiva, que transmiten el nombre a sus asentamiento rural, "qarya" o alquería; para ello, es necesario que el linaje cuente con la estabilidad aportada por la patrilinealidad, excluyendo al elemento femenino de la herencia, y recurriendo con frecuencia a la endogamia ${ }^{223}$. A diferencia de las investigaciones de este autor en la zona levantina, no hemos podido relacionar estos topónimos con núcleos de población ${ }^{224}$; en cambio, sí tenemos una referencia a la propiedad colectiva ejercida por estos clanes. Nos referimos a "los de Ben Cafla" que figuran como linderos de una pieza en el término calagurritano de Torrescas hacia 1165225; en la siguiente centuria, este grupo familiar acaba dando su nombre a una acequia, un molino y un paraje, denominados todos "Vencabla" (actual Mencabla), al oeste de la ciudad"22.

219. RODRÍGUEZ Y RODRÍGUEZ DE LAMA, I.: Colección Diplomática...II, doc. 29, 58, $72 \mathrm{~m}, 122, \ldots$

220. Aunque considera de tipo "Beni" los prefijos "Bini", "Bene", "Bena" y "Bani", estima más dudosos los de tipo "Ben", "Ven" o "Vin", aunque a veces pueden derivar de formas en "Beni". GUICHARD, P.: Al-Andalus. Estructura antropológica de una sociedad islámica en Occidente. Barcelona, 1973, pp. 425 y 426.

221. RODRÍGUEZ Y RODRÍGUEZ DE LAMA, I.: Colección Diplomática...II, doc. 222a. Colección Diplomática...IV, docs. 146, 164, 243 y 250.

222. RODRÍGUEZ Y RODRÍGUEZ DE LAMA, I.: Colección Diplomática...II, doc. 83. Colección Diplomática...IV, doc. 61. SAÍNZ RIPA, E. y ORTEGA LÓPEZ, A.: Documentación Calagurritana..., docs. 7 y 162. En el siglo XVIII se menciona el término de "Campo baxo o hoyo del ambazo". CRISTÓBAL FERNÁNDEZ, E. y MARTíN ESCORZA, C.: “Un proyecto de acequia..., p. 222.

223. GUICHARD, P.: Al-Andalus. Estructura antropológica de una sociedad islámica en Occidente. Granada, 1995, pp. 409-415. Aunque Barceló profundiza en este planteamiento, la hipótesis de Guichard no convence a otros autores como Azuar, Barceló Torres, Manzano, Epalza, Vallvé,... MARTÍNEZ ENAMORADO, V.: Al-Andalus desde la periferia. La formación de una sociedad musulmana en tierras malagueñas (siglos VIII-X). Málaga, 2003, pp. 481 y ss.

224. ¿Debido a lo temprano de su cronología, pues la reconquista cristiana no permite cristalizar un proceso de sedentarización?; que, en cambio, sí pudo llevarse a cabo en Sarq AlAndalus en el siglo XII, cuando se fechan allí muchos de estos topónimos. MARTíNEZ ENAMORADO, V.: Al-Andalus..., p. 479.

225. Más dudosa es la mención de la pieza "qui fuit de Vengaliella" en la Torre de Albogozan hacia 1132. RODRÍGUEZ Y RODRÍGUEZ DE LAMA, I.: Colección Diplomática...II, docs. 99 y 222 a.

226. RODRÍGUEZ Y RODRÍGUEZ DE LAMA, I.: Colección Diplomática...IV, docs. 146, 164,243 y 250. El hecho de que este grupo posea bienes fuera del espacio donde van a cristalizar como topónimo ipuede deberse a una partición del linaje, uno de los recursos empleados 
Si interpretamos dichos topónimos en clave gentilicia, debemos preguntarnos el origen de estos grupos familiares. Guichard considera que esta toponimia clánica no es fruto de un proceso de aculturación o islamización sino que precisa de la estabilidad estructural de "un aporte étnico árabe y principalmente norteafricano" ${ }^{227}$. Martínez Enamorado confirma la mayor abundancia de este tipo de topónimos entre los bereberes con respecto a los árabes; en cambio, Oliver Asín diferencia entre los sufijos "bani-" y "banu-", habituales entre los bereberes, y los "beni-", más propios de árabes ${ }^{228}$, que serían los que encontramos en Calahorra. En caso de tratarse de un aporte demográfico exógeno, éste pudo instalarse en el campo calagurritano a raíz de la reconstrucción y repoblación de Calahorra por parte de Gālib; posiblemente, dentro del proceso colonizador vigente desde finales del siglo X en la Marca Superior, cuyo objetivo es organizar la frontera en función de los núcleos urbanos ${ }^{229}$. También puede tratarse de grupos agnaticios, ya presentes en la zona, que abandonan sus hábitos seminómadas tras la estabilidad experimentada a partir del 968, asentándose de un modo definitivo en torno a Calahorra; de este modo, se configuran las alquerías de Pego o San Carlos de la Rápita en Sharq al Andalus ${ }^{230}$.

En el conjunto de al-Andalus, este protagonismo de la propiedad colectiva de los grupos gentilicios empieza pronto a desdibujarse debido básicamente a dos factores interrelacionados: la expansión urbana y la organización militar de la frontera. Entre finales del siglo X y la primera mitad de la siguiente centuria, la reforma amirí reorganiza la frontera en función de los núcleos urbanos, cuya repoblación y fortificación se promueve, permitiendo a los miembros del ejército recaudar impuestos sobre las comunidades rurales e, incluso, recibiendo estos, y los funcionarios estatales, concesiones de casa y tierras como pago $^{231}$. De este modo, se configura una aristocracia que asienta su poder en su vinculación al aparato del estado, mediante la participación en el cobro de impuestos, y en la posesión de latifundios, ya sea en régimen de propiedad plena o de concesiones estatales ${ }^{232}$. Este proceso de configuración de importantes patrimonios fundiarios a principios del siglo XI como consecuencia de la política amirí está constatado por Sénac y Eritja Ciuró en las actuales provincias de Huesca y Lleida, respectivamente, dentro de la misma Marca Superior de al-Andalus al igual que Calahorra ${ }^{233}$.

para defender la propiedad colectiva según Barceló? MARTíNEZ ENAMORADO, V.: Al-Andalus..., p. 481.

227. GUICHARD, P.: Al-Andalus. Estructura antropológica..., pp. 411 y s.

228. MARTÍNEZ ENAMORADO, V.: Al-Andalus..., pp. 478 y s.

229. ERITJA CIURÓ, X.: De l'Almunia a la Turris..., pp. 32 y s.

230. GUICHARD, P.: Al-Andalus. Estructura antropológica..., p. 436.

231. CHALMETA, P.: “El concepto..., p. 21.

232. GUICHARD, P.: Al-Andalus frente a la conquista cristiana. Los musulmanes de Valencia (siglos XI-XIII). Valencia, 2001, pp. 648 y ss.

233. "Les noms des propriétaires de ces domaines tels Ibn Zebala ou Abinabderame, semblent indiquer qu'il s'agit de fondations récentes remontant à une ou deux générations et il 
Esta participación de la aristocracia en la recaudación tributaria transforma no sólo la estructura de la propiedad en estos núcleos rurales, sino también su propia organización social basada en la apropiación comunal del territorio ${ }^{234}$. Se produzca o no un incremento de la presión fiscal ${ }^{235}$, existe una evolución, en virtud de la tributación exigida desde la urbe, desde estos asentamientos explotados por clanes gentilicios hacia grandes propiedades individuales trabajadas por colonos o aparceros que, en ocasiones, podrían ser los mismos miembros de la diluida colectividad gentilicia ${ }^{236}$. Las comunidades rurales, aún transformadas en grandes explotaciones privadas, conservan la integridad territorial de la antigua propiedad colectiva ${ }^{237}$. Estas grandes explotaciones o cortijadas, registradas en la documentación latina como "almunias" o "torres", serían las "day'a-diyā", palabra que, precisamente, deriva de una imposición fiscal ${ }^{238}$. La expansión de la gran propiedad rompe el sentimiento de pertenencia a una comunidad, aportado por la propiedad colectiva, minando la capacidad de resistencia frente a la presión cristiana; si a ello le añadimos que esta aristocracia basa su preeminencia, no en el ejercicio directo de la actividad armada (delegado en tropas mercenarias), sino en la acumulación de bienes y en la percepción tributaria ${ }^{239}$, no nos sorprende el desmoronamiento de la Marca Superior de al-Andalus durante los siglos XI y XII, siendo la reconquista de Calahorra en 1045 su primer acto.

En Calahorra, justo en el momento reconquistador, documentamos grandes explotaciones cuyos orígenes nos remiten al periodo islámico ${ }^{240}$. Así, sólo un mes después de dicho acontecimiento, García Garcés III dona al monasterio de

permis de mettre en relation leur aparittion avec les bouleversements fonciers et les confiscations de terres signalées par al-Turtushi à la fin de l'époque amiride". SÉNAC, Ph.: "Stratigraphie..., p. 69. ERITJA CIURÓ, X.: De l'Almunia a la Turris..., p. 39.

234. ERITJA I CIURÓ, X.: De l'Almunia a la Turris..., pp. 36 y ss.

235. Para Eritja i Ciuró, Barceló y Sénac, esto supone un aumento de la presión fiscal sobre dichas comunidades; en cambio, Guichard estima que el equilibrio entre la ciudad y el campo existente en la Valencia andalusí se basa en una fiscalidad moderada dentro de los límites impuestos por la "sari 'a" y, en la misma línea, Chalmeta apunta que los țugūr" cuentan con el privilegio fiscal de ser "ard al- 'ušr", "tierras del diezmo" donde este impuesto es el único exigido. Ibidem. SÉNAC, Ph.: "Stratigraphie..., p. 69. BARCELÓ, M.: "Un estudio sobre la estructura fiscal y procedimientos contables del emirato de Córdoba". Acta Mediaevalia, V-VI (1985-86), pp. 45-72. GUICHARD, P.: Al-Andalus frente a la conquista cristiana..., pp. 649 y s. CHALMETA, P.: "El concepto..., p. 22.

236. En Valencia, Ibn Ḥayyān nos relata como la presión fiscal ejercida por los emires Mubārak y Muzaffar entre los años 1010 y 1017 obliga a los campesinos a abandonar sus aldeas frente a los grandes propietarios para terminar trabajando para estos. GUICHARD, P.: "Crecimiento urbano..., p. 169 (citado por SÉNAC, Ph.: "Stratigraphie..., p. 69).

237. ERITJA I CIURÓ, X.: "Entre la Lleida andalusí..., pp. 32 y ss.

238. Ibidem, pp. 25 y ss. De l'Almunia a la Turris..., p. 37.

239. SÉNAC, Ph.: "Stratigraphie..., p. 70.

240. ERITJA CIURÓ, X.: De l'Almunia a la Turris..., p. 35. 
San Millán de la Cogolla una "hereditatem plurimam, obtimam, non divisa, sed partem unam integram" ubicada en pleno regadío calagurritano, entre el río Molinar y la propia urbe. Esta heredad se configura durante el dominio musulmán, incluso bastante antes del 1045, pues ya entonces se trata de una heredad que "omnibus cives est cognita"241. Otro ejemplo sería la "domum...cum suis exitis, terris, vineis et ortis" exenta de la jurisdicción del señor de Calahorra, donada por Sancho Garcés IV al monasterio de San Martín de Albelda hacia el 1062, que nosotros identificamos con la coetánea "Diacanga de Albelda" o molino de San Felices ${ }^{242}$. Sin embargo, en estos casos ignoramos si el anterior titular de estas grandes explotaciones fue un gran propietario o si se trataba del bien colectivo de un grupo familiar.

Más claros al respecto resultan aquellos asentamientos convertidos en grandes propiedades individuales, las "diyā" o cortijadas denominadas "torres" o "almunias" por los escribas latinos. Una de ellas es la Torre de Almudebar, donada "cum totis terminis suis" por los monarcas Alfonso VI de Castilla y Alfonso I de Aragón en 1100 y 1132, respectivamente. Del mismo modo, la etimología de la Torre de Albogozan quizás contenga el nombre su propietario islámico, "Abū Gen"243. En cuanto a la Almunia de Calahorra, entregada por Fernando III al obispo de Calahorra en $1222^{244}$, junto a su función residencial, está clara su condición de gran explotación de regadío vinculada a la propiedad privada de la aristocracia; ambas características seguramente ya las reuniese durante el periodo andalusí2 ${ }^{45}$. Sobre los titulares musulmanes de estas propiedades, aristócratas vinculados al aparato estatal en la Calahorra islámica, la única mención es posterior a la reconquista, cuando en 1074 el rey pamplonés Sancho Garcés IV dona unas casas en Calahorra "quibus fuerant del Çhakib Ibierno iudex" ${ }^{246}$. La titularidad regia del inmueble nos invita a pensar que desempeña dicho cargo durante el periodo islámico, pasando sus bienes al realengo tras la conquista cristiana; no obstante ignoramos la naturaleza de sus responsabilidades y si el ejercicio de sus funciones se lleva a cabo dentro de la comunidad hebrea o de la musulmana.

241. "id est de illo balliolo de Carta usque ad Spino, iuxta rivo molinare; et de alia parte via que dicunt de Acutu partis aquam ab aspecto urbem sitam". UBIETO ARTETA, A.: Cartulario de San Millán..., doc. 235. Otro ejemplo de gran explotación podría ser la heredad de Almonecer, donada por doña Eugenia a la catedral de Calahorra hacia el 1100, pero su origen islámico resulta mucho más dudoso. RODRÍGUEZ Y RODRÍGUEZ DE LAMA, I.: Colección Diplomática...II, doc. 45.

242. UBIETO ARTETA, A.: Cartulario de Albelda..., docs. 44 y 45.

243. También puede referirse a un propietario individual el topónimo "illo Petrecal de Avvincia" documentado hacia 1165. RODRíGUEZ Y RODRíGUEZ DE LAMA, I.: Colección Diplomática...II, docs. $83 f$ y 99.

244. Ibidem, docs. 47 y 101. Colección Diplomática...III, doc. 484.

245. ERITJA CIURÓ, X.: De l'Almunia a la Turris..., pp. 16 y s. "Entre la Lleida andalusí..., pp. 25 y ss. SÉNAC, Ph.: , p. 68.

246. RODRÍGUEZ Y RODRÍGUEZ DE LAMA, I.: Colección Diplomática...II, doc. 29. 
La existencia de una toponimia de posible origen gentilicio, y de grandes explotaciones individuales, nos invita a sugerir la hipótesis de una evolución, desde la propiedad colectiva de dichos grupos familiares a la gran propiedad individual en el marco temporal de la Calahorra islámica. Se trataría de una transformación similar a la observada en otras localidades de la Marca Superior de al-Andalus como Huesca o Lleida. Así, en los últimos decenios de la Calahorra islámica nos encontraríamos con una ciudad fronteriza en expansión, gracias a la estabilidad política y al desarrollo del regadío. Esta urbe va organizando en su provecho el entorno agrario circundante, y las comunidades rurales en él ubicadas, mediante la imposición del tributo como contrapartida por la seguridad dispensada por el "hișn" y para el mantenimiento de elementos públicos como las murallas, los espacios de culto, la alhóndiga,... En dichas circunstancias, surge una aristocracia, militar o vinculada a responsabilidades religiosoadministrativas ${ }^{247}$, gracias a su participación en la recaudación tributaria y a la adquisición de propiedades fundiarias. Así, se van quebrando las comunidades gentilicias que pudiesen existir previamente en los núcleos de población dispersos por el campo calagurritano ${ }^{248}$; algunos de estos asentamientos se convierten en cortijos desde donde se organizan las grandes explotaciones que documentan los conquistadores cristianos a partir del 30 de abril de 1045.

247. ERITJA CIURÓ, X.: De l'Almunia a la Turris..., pp. 35 y s.

248. "Vengaliella", propietario de una pieza en la Torre de Albogozan hacia 1132, podría ser el anterior grupo gentilicio titular de esta explotación. Asimismo, los "Ben Bazo", grupo familiar que da lugar al citado topónimo, pero hacia 1100 es citado un individuo, "Iben bazo", lindero de un agro en la "Pontiziella de la Vetada" y, medio siglo más tarde, "Dominicus lohannes de Bombazo o iben Bazo" figura entre los vecinos de Calahorra. Por último, hacia 1175, documentamos un patronímico de prefijo "Avin-" al mencionarse una pieza "in fondon de illo Petrecal de Avvincia". RODRíGUEZ Y RODRÍGUEZ DE LAMA, I.: Colección Diplomática...ll, docs. 45, 83f, 99 y 138. ¿llustran estos ejemplos el proceso de disolución de las comunidades clánicas y la evolución desde la propiedad colectiva familiar a la individual? La escasez de datos, y las dificultades a la hora de diferenciar entre prefijos "Beni" y "Avin" dentro de la documentación latina, nos impiden extraer conclusiones al respecto. 